\title{
Keratinocyte Carcinoma and Photoprevention: The Protective Actions of Repurposed Pharmaceuticals, Phytochemicals and Vitamins
}

\author{
Celina Pihl 1,2,*(D), Katrine Togsverd-Bo ${ }^{1,3}$, Flemming Andersen ${ }^{4,5}$, Merete Haedersdal ${ }^{1,3} \mathbb{D}$, Peter Bjerring 4 \\ and Catharina Margrethe Lerche ${ }^{1,2}$ (D)
}

Citation: Pihl, C.; Togsverd-Bo, K.; Andersen, F.; Haedersdal, M.; Bjerring, P.; Lerche, C.M. Keratinocyte Carcinoma and Photoprevention: The Protective Actions of Repurposed Pharmaceuticals, Phytochemicals and Vitamins. Cancers 2021, 13, 3684. https://doi.org/10.3390/ cancers13153684

Academic Editors: Salvador González, Melissa Gill and Ángeles Juarranz

Received: 29 June 2021

Accepted: 18 July 2021

Published: 22 July 2021

Publisher's Note: MDPI stays neutral with regard to jurisdictional claims in published maps and institutional affiliations.

Copyright: (c) 2021 by the authors. Licensee MDPI, Basel, Switzerland. This article is an open access article distributed under the terms and conditions of the Creative Commons Attribution (CC BY) license (https:// creativecommons.org/licenses/by/ $4.0 /)$
1 Department of Dermatology, Copenhagen University Hospital-Bispebjerg and Frederiksberg, 2400 Copenhagen, Denmark; Katrine.Togsverd-Bo@regionh.dk (K.T.-B.); mhaedersdal@dadlnet.dk (M.H.); Catharina.Margrethe.Lerche@regionh.dk (C.M.L.)

2 Department of Pharmacy, University of Copenhagen, 2100 Copenhagen, Denmark

3 Department of Clinical Medicine, University of Copenhagen, 2100 Copenhagen, Denmark

4 Department of Dermatology, Aalborg University Hospital, 9100 Aalborg, Denmark; fan@molholm.dk (F.A.); email@peterbjerring.dk (P.B.)

5 Private Hospital Molholm, 7100 Vejle, Denmark

* Correspondence: Celina.pihl@regionh.dk

Simple Summary: Keratinocyte carcinoma is the most common type of cancer. Sun exposure and ultraviolet radiation are significant contributors to the development of carcinogenesis, mediated by DNA damage, increased oxidative stress, inflammation, immunosuppression and dysregulated signal transduction. Photoprevention involves using different compounds to delay or prevent ultraviolet radiation-induced skin cancer. In this review, we look at new avenues for systemic photoprevention that are based on pharmaceuticals, plant-derived phytochemicals and vitamins. We also investigate the mechanisms underlying these strategies for preventing the onset of carcinogenesis.

Abstract: Ultraviolet radiation (UVR) arising from sun exposure represents a major risk factor in the development of keratinocyte carcinomas (KCs). UVR exposure induces dysregulated signal transduction, oxidative stress, inflammation, immunosuppression and DNA damage, all of which promote the induction and development of photocarcinogenesis. Because the incidence of KCs is increasing, better prevention strategies are necessary. In the concept of photoprevention, protective compounds are administered either topically or systemically to prevent the effects of UVR and the development of skin cancer. In this review, we provide descriptions of the pathways underlying photocarcinogenesis and an overview of selected photoprotective compounds, such as repurposed pharmaceuticals, plant-derived phytochemicals and vitamins. We discuss the protective potential of these compounds and their effects in pre-clinical and human trials, summarising the mechanisms of action involved in preventing photocarcinogenesis.

Keywords: cancer; cancer prevention; keratinocyte carcinoma; mechanism of action; photocarcinogenesis; phytochemicals; skin; skin cancer; ultraviolet radiation

\section{Introduction to Photocarcinogenesis}

Keratinocyte carcinoma (KC) — consisting of basal cell carcinomas (BCCs) and squamous cell carcinomas (SCCs) - is the most common cancer worldwide [1]. Carcinogenesis is strongly impacted by sun exposure, demonstrated by $90 \%$ of KC cases being associated with ultraviolet (UV) radiation (UVR) exposure [2]. UVR consists of UVA (320-400 nm), UVB (280-320 nm) and UVC (200-280 nm), with only the former two reaching the earth [3]. UVR exposure primarily affects the skin. Here, UVR is almost entirely absorbed by the epidermal cells, inducing adverse effects that contribute to UV-induced carcinogenesis, or photocarcinogenesis. 
Chemical prevention of photocarcinogenesis-or chemical photoprevention-involves the administration of compounds that counteract the effects of UVR. This can be achieved by direct absorption or reflection of UV rays-often by topical application —or by targeting the biological effects of UVR systemically.

In this review, we consider five events induced by UVR that contribute to photocarcinogenesis: DNA damage, oxidative stress, inflammation, immunosuppression and signal transduction (Figure 1A-C).

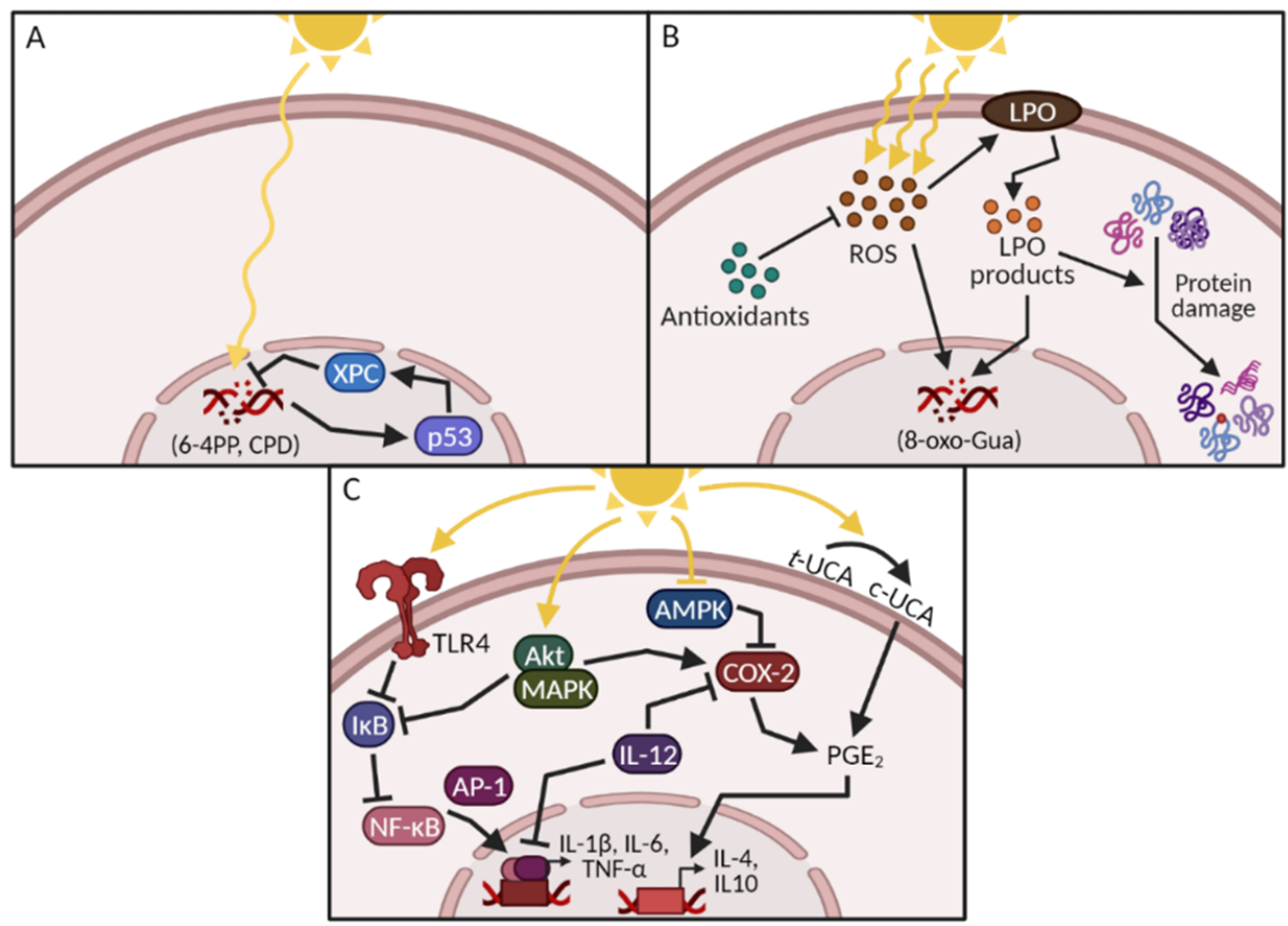

Figure 1. Simplified schematic of (A): UV-induced DNA damage caused by direct UV absorption by the DNA molecules resulting in DNA lesions such as 6-4 photoproducts (6-4PPs) or cyclobutane pyrimidine dimers (CPDs) which are repaired by XPC and the nuclear excision repair pathway; (B): UV-induced oxidative stress caused by increased reactive oxygen species (ROS) production resulting in damaged DNA (8-oxo-hydroxyguanine lesions), lipid (lipid peroxidation; LPO) and protein (carbonylation and other irreversible changes) molecules; (C): UV-induced inflammation, immunosuppression and signal transduction caused by dysregulated mitogen-activated protein kinase (MAPK) activity resulting in activation and transcription of inflammatory mediators. Furthermore, UV radiation induces immunosuppressive mediators via the photoisomersiation of trans-urocanic acid (UCA) to cis-UCA. Abbreviations: AMPK: AMP-activated protein kinase, AP-1: activator protein 1, COX-2: cyclooxygenase 2, IL: interleukin, $\mathrm{PGE}_{2}$ : prostaglandin $\mathrm{E}_{2}$, TLR4: Toll-like receptor 4.

\subsection{UV-Induced DNA Damage}

A direct target of UVR exposure is DNA. UVR exposure can result in DNA strand breaks and the formation of 6-4 photoproducts or cyclobutane pyrimidine dimers (CPDs) [4,5]. These lesions are formed in locations with two adjacent pyrimidines and are removed by nucleotide excision repair (NER). In brief, the repair mechanism consists of recognition, incision and replication steps that remove and replace the damaged DNA [6], carried out by the xeroderma pigmentosum family of proteins (XPA-G) (Figure 1A). In particular, XPC reportedly plays a key role in recognising UV-induced DNA damage, as confirmed by mutations and deletions often found in SCC patients [7].

If the NER pathway does not function correctly and the dimers are not repaired, $\mathrm{CC} \rightarrow \mathrm{TT}$ tandem mutations-also called thymine dimers-may be introduced. These are often found in the p53 gene of SCC patients and are recognised as an indicator of UV 
exposure [8]. Mutations in p53 cause genomic instability and generate a microenvironment that is conducive to tumour development and progression [9]. Together with mutations in other key proteins, this causes an imbalance in tumour suppressor genes and oncogenes, facilitating photocarcinogenesis (Figure 2).

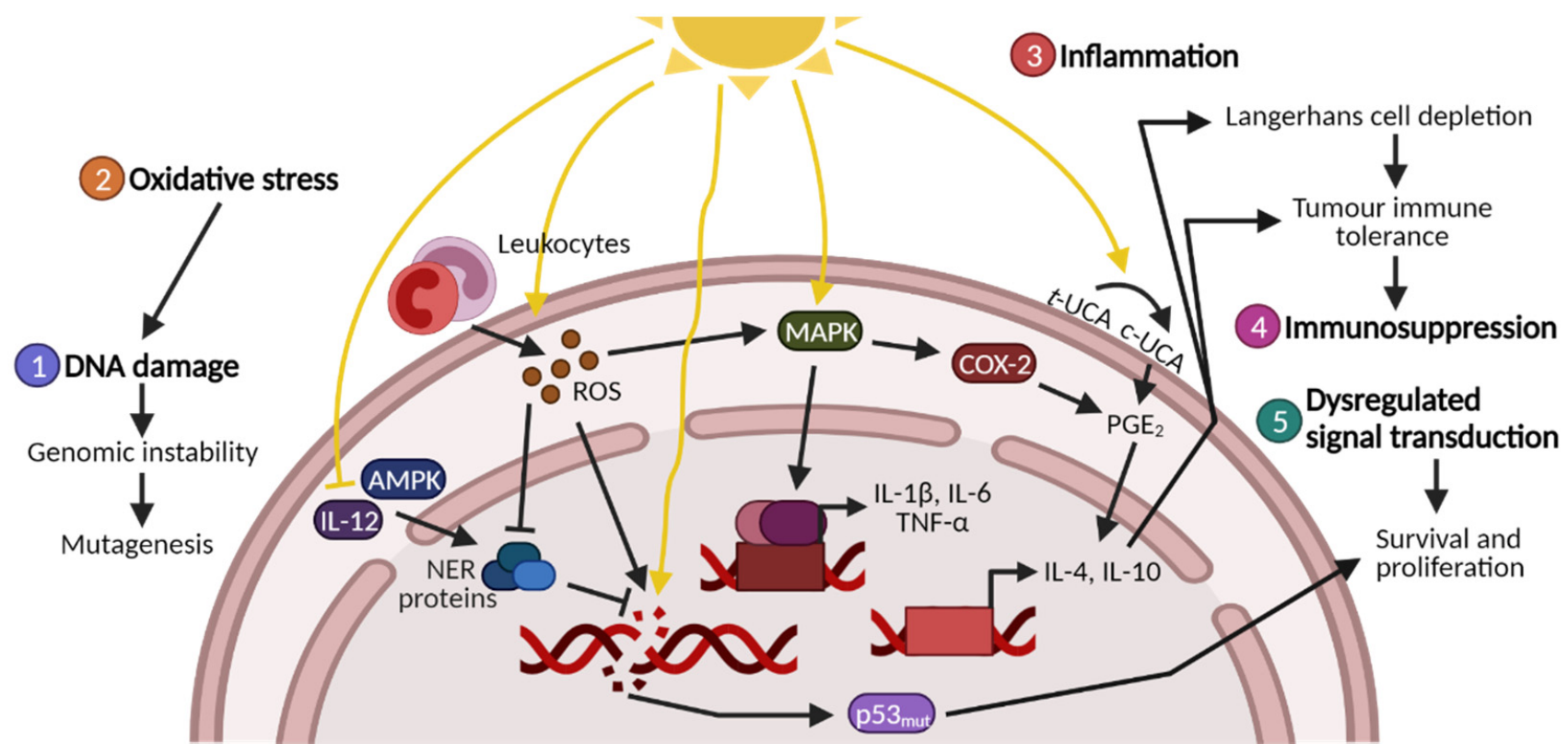

Figure 2. Crosstalk linking UV-induced events: DNA damage, oxidative stress, inflammation, immunosuppression and dysregulated signal transduction as presented in Figure 1. All five events are involved in crosstalk, creating an environment that promotes photocarcinogenesis. Abbreviations: AMPK: AMP-activated protein kinase, AP-1: activator protein 1, COX-2: cyclooxygenase 2, IL: interleukin, MAPK: mitogen-activated protein kinase, NER: nuclear excision repair, PGE $_{2}$ : prostaglandin $\mathrm{E}_{2}$, ROS: reactive oxygen species, TNF: tumour necrosis factor, $t$ (trans)/c(cis)-UCA: urocanic acid.

\subsection{UV-Induced Oxidative Stress and Protein Damage}

Exposure to UVR increases the production and release of reactive nitrogen and oxygen species (ROS) $[10,11]$. Although the skin contains several endogenous antioxidants that can counteract endogenous ROS production (Table 1), the increased release of pro-oxidants overwhelms the system and depletes the antioxidant capacity [12]. Thus, the reactive species remain unchecked, causing oxidative stress to DNA, lipid and protein molecules (Figure 1B).

Table 1. Non-exhaustive list of reactive species generated by UV radiation and endogenous antioxidants found in the skin.

\begin{tabular}{cccc}
\hline \multicolumn{2}{c}{ Reactive Species } & \multicolumn{2}{c}{ Antioxidants } \\
\hline Hydrogen peroxide $\left(\mathrm{H}_{2} \mathrm{O}_{2}\right)$ & Hydroperoxyl $\left(\mathrm{HO}_{2}\right)$ & Catalase & Glutathione \\
\hline Hydroxyl radical $(\mathrm{OH})$ & Nitric oxide $(\mathrm{NO})$ & $\begin{array}{c}\text { Glutathione } \\
\text { peroxidase }\end{array}$ & $\begin{array}{c}\text { Superoxide } \\
\text { dismutase }\end{array}$ \\
\hline Singlet oxygen $\left({ }^{1} \mathrm{O}_{2}\right)$ & Superoxide $\left(\mathrm{O}^{-}{ }_{2}\right)$ & Vitamin $\mathrm{C}$ & Vitamin $\mathrm{E}$ \\
\hline
\end{tabular}

Guanine nucleobases in the DNA are particularly sensitive to oxidation [13]. The introduction of oxidised bases such as 8-hydroxyguanine (8-oxo-Gua) may cause G:C $\rightarrow$ T:A transversions which, together with other DNA lesions and impaired NER components, enhance the mutagenic potential of UV exposure [14,15].

Lipid peroxidation (LPO) represents the major oxidative damage affecting lipids. Here, ROS attack the allylic carbon atom of a lipid molecule, often polyunsaturated fatty acids, and abstract the hydrogen molecule, creating a lipid radical. The lipid then reacts with 
oxygen to form a lipid peroxyl radical which, in turn, can abstract hydrogen molecules from nearby lipids, initiating a chain reaction and forming new radicals [16]. During homeostasis, a termination step follows in which an antioxidant, often vitamin E, donates a hydrogen molecule to the lipid peroxyl radical to stop further reactions. Vitamin $\mathrm{E}$ is then reduced via a cycle involving vitamin $\mathrm{C}$, glutathione and $\mathrm{NAD}(\mathrm{P}) \mathrm{H}$, restoring its antioxidant activity [17]. However, as the ratio of antioxidants to ROS is reduced during UVR exposure, the LPO reactions continue to cause damage.

One target of LPO is the phospholipids in the cell membranes. Damage impairs membrane integrity, which affects the activity of membrane-bound proteins and contributes to a pro-apoptotic state [18]. Secondary aldehyde products of LPO, such as malondialdehyde and 4-hydroxynonenal, can also react with thiol and amino groups, leading to changes in protein activity, binding or turnover as a result of altered side chains, aggregation, fragmentation or conformational changes $[19,20]$. In addition to direct interaction with nucleosides to form adducts, malondialdehyde also inhibits the NER pathway, leaving cells vulnerable to UV-induced mutagenesis (Figures $1 \mathrm{~B}$ and 2).

Another effect of oxidative stress is protein carbonylation. Here, reactive carbonyl groups-e.g., originating from aldehydes-are introduced into proteins via oxidation of amino acid side chains [21]. This modification is irreversible and, because carbonylated proteins are prone to aggregation, these proteins must be degraded [22]. Finally, ROS can mimic the effects of tumour promoters, which contributes to the transformation of cells [23].

\subsection{UV-Induced Inflammation, Immunosuppression and Signal Transduction}

UVR exposure elicits a prolonged inflammatory response that presents as erythema, hyperplasia and oedema caused by increases in vascular flow and permeability. This is triggered by the release of inflammatory mediators such as cytokines and chemokines that recruit leukocytes to the irradiation site [24]. These cells contribute to the inflammatory state which also stimulates ROS production, thereby increasing oxidative stress (Figure 2).

One of these mediators is the transcription factor NF- $\mathrm{BB}$, which is sequestered in the cytosol by the inhibitory protein I $\kappa$ B. Upon UV exposure, I $\kappa$ B is targeted for degradation via mitogen-activated protein kinase (MAPK) signalling, facilitating NF- $\kappa B^{\prime}$ s nuclear translocation to regulate target gene expression $[25,26]$. In particular, NF- $\mathrm{KB}$ regulates the expression of the pro-angiogenic permeability factor vascular endothelial growth factor, as well as interleukin (IL)-1 $\beta$, IL-6 and tumour necrosis factor (TNF- $\alpha$ ), all of which are implicated in photocarcinogenesis (Figure 1C) [27].

Another marker of UV-induced inflammation is the upregulation of cyclooxygenase (COX)-2 expression induced by ROS and the MAPK pathways [28]. The COX enzymes include the constitutive COX-1 and the inducible COX-2 forms. The COX enzymes stimulate the synthesis of prostaglandins (PGs), where $\mathrm{PGE}_{2}$ is produced abundantly in the skin. PG-stimulated signalling promotes angiogenesis, infiltration of leukocytes at the irradiation site and cellular proliferation $[29,30]$.

UVR exposure also reportedly acts immunosuppressive. Here, UV exposure targets the antigen-presenting Langerhans cells, impairing their function. UVR exposure reduces the expression of MHC II and co-stimulatory molecules, thereby preventing antigen presentation [31,32]. Another sign of chronic UVR exposure is Langerhans cell depletion, either via migration to lymph nodes or-when UV doses are high—apoptotic cell death [33].

Trans-urocanic acid (UCA) is a histidine metabolite located in the skin, where it provides endogenous protection by acting as a photoreceptor. Upon UV exposure, trans-UCA is photoisomerised to cis-UCA, inactivating its photoprotective properties [34,35]. Furthermore, cis-UCA also induces the release of $\mathrm{PGE}_{2}$, which activates a cascade of suppressive cytokines resulting in the expression of IL-4 and IL-10 (Figures 1C and 2) [36,37]. IL-10 is a key immunosuppressive mediator involved in impairing the antigen-presenting cell (APC) function of Langerhans cells [38], as well as preventing other APCs from stimulating Th-cells [39]. 
UVR induced immunomodulation presents a dynamic range of cellular states from inflammatory to immunotolerance to immunosuppression, creating an environment that supports and promotes carcinogenesis [40].

Whether it is UV-induced DNA damage, oxidative stress, inflammation or immunosuppression, signal transduction plays an important role in providing the optimal conditions for tumour development. As with many other cancer types, signal transduction during photocarcinogenesis is heavily impacted by MAPK signalling via p38, JNK and ERK and the subsequent activation of NF- $\mathrm{KB}$ and activator protein 1 (AP-1), as well as the inactivation of AMP-activated protein kinase (AMPK) (Figure 1C, Figure 2) [41,42].

\subsection{Photocarcinogenesis and Photoprotectants}

During photocarcinogenesis, UV-induced DNA damage, oxidative stress, inflammation, immunosuppression and dysregulated signal transduction all participate in crosstalk as part of the initiation, development and progression of skin cancer (Figure 2). Therefore, all five categories must be evaluated to identify potential photoprotectants.

A compound's photoprotective potential is usually evaluated in skin-derived cell and mouse models with human trials later on when the photoprotective potential has been established. The immunocompetent hairless mouse model is frequently used in these studies as tumour development can be monitored throughout the intervention period [43].

In this review, we have included five different categories of compounds from pharmaceuticals, phytochemicals and vitamins that have exhibited photoprotective properties. The purpose of this strategy was to strike a balance between a comprehensive description of a given compound with its mechanism of action and discussing the diverse effects of compounds within these three groups. These fifteen categories have been included because they each represent a characteristic photoprotective mechanism. Consequently, we illustrate specific aspects of how to target UV-induced effects using candidate compounds and we simultaneously provide insight into the properties required to prevent skin cancer. A range of studies is described, from initial testing in mouse models to year-long human trials. This approach emphasises the progression within this research field as well as the compounds that have emerged as potential photoprotectants. In Tables 2-4, we provide an overview of the various protective mechanisms and present results from photocarcinogenesis prevention studies in humans and mouse models.

\section{Pharmaceuticals: From Repurposing to Prevention}

\subsection{Non-Steroidal Anti-Inflammatory Drugs}

Some of the most frequently prescribed drugs worldwide are the non-steroidal antiinflammatory drugs (NSAIDs). These are commonly used as painkillers for numerous conditions because of their analgesic and anti-inflammatory properties. NSAIDs interfere with PG-synthesis through inhibition of the COX enzymes [44]. COX-2 induction is an important mediator of photocarcinogenesis. Therefore, COX-2 specific and non-specific NSAIDs presented as an attractive source for photoprotection. However, as the field has progressed, pharmaceutical photoprevention has increasingly focused on repurposing drugs with anticarcinogenic properties and evaluating whether these drugs could be used in photoprotection. NSAIDs such as celecoxib, nimesulide, indomethacin and acetylsalicylic acid have reportedly exhibited protective effects during in vivo studies. These NSAIDS delayed tumour onset and reduced tumour incidence, size and progression, as well as triggering tumour regression in some cases [45,46]. The anti-tumour effects were accompanied by reduced DNA damage and inflammation, decreased MAPK, NF- $\mathrm{KB}$ and COX-2 activation and $\mathrm{PGE}_{2}$ synthesis [47-49].

Consequently, NSAIDs were tested in clinical trials. In an 11-month clinical trial, administration of $400 \mathrm{mg}$ celecoxib daily to subjects with premalignant actinic keratoses (AKs) reduced the total number of KCs as well as BCCs and SCCs individually [50]. In another study, topical application of $1 \%$ piroxicam-a non-specific NSAID—-triggered regression in $48 \%$ of AKs included in the study (Table 2) [51]. 
However, although NSAIDs have demonstrated photoprotective potential in both mouse and human studies, other studies have described the potentially adverse side effects of prolonged NSAID use. These include increased risk of cardiovascular events [52], gastrointestinal bleeding [53] and renal failure [54].

\subsection{AMPK Activators: Metformin}

Increasing evidence has implicated AMPK as a potential target for cancer therapies [55]. AMPK as an energy and nutrient sensor can interact with p53 via metabolic checkpoints to induce cell cycle arrest [56,57]. Additionally, tumours from UV-irradiated human and murine skin display decreased AMPK activation [41], suggesting a role for AMPK activation in photoprotection. Metformin is commonly used to treat diabetes by inhibiting protein kinase A and activating AMPK, leading to decreased gluconeogenesis in the liver and increased insulin sensitivity in target tissues [58]. Interestingly, metformin treatment is reportedly associated with a $31 \%$ decrease in overall cancer risk, compared to other antidiabetic treatments [59].

In keratinocytes, incubation with metformin protected against UV-induced inflammation, as demonstrated by impaired NF- $\mathrm{kB}$ activity and reductions in IL-1 $\beta$, IL- 6 and TNF- $\alpha$ expression [60]. Similarly, a study on nude mice with SCC A431 tumour-cell xenografts reported impaired NF- $\mathrm{kB}$ activity as well as reduced COX-2 expression following injection with metformin [61].

Metformin reduced ROS formation and expression of matrix metalloproteinase (MMP) 1 and 3 in vitro [62]. During homeostasis, MMPs partake in remodelling and degradation of the extracellular matrix [63]. However, MMPs can also stimulate tumour development and angiogenesis. Furthermore, topical application of metformin in hairless mice increased CPD repair six hours after UVR exposure [41]. In xenografted mice, injection with metformin also protected against UV-induced proliferation, inducing apoptosis in the tumours along with reductions in protein kinase B (Akt), MAPK and NF- $\mathrm{kB}$ signalling [61]. Moreover, metformin may specifically target the skin's cancer stem cell diaspora [64,65], further illustrating its photoprotective potential.

In hairless mice, topical and oral administration of metformin delayed tumour onset, decreased tumour multiplicity and volume and stimulated DNA repair (Table 2) [41]. In vitro studies using AMPK-knockout cells reported that metformin-induced DNA repair was dependent on AMPK activation [41].

There have been no clinical studies on the effect of metformin on KCs. However, a population-wide study in Taiwanese diabetic patients reported a significantly lower risk of skin cancer incidence in metformin-treated subjects compared to those who had never received metformin [66]. Another recent study across the Icelandic population found a significantly lower risk of BCCs, but not SCCs, following metformin use [67].

Metformin, therefore, represents a promising candidate for photoprotection, but more studies are needed, namely clinical trials, to investigate its effects. Furthermore, AMPK activators such as 5-aminoimidazole-4-carboxamide ribonucleotide (AICAR) [41] and phenformin $[68,69]$ should also be investigated as potential photoprotectants.

\subsection{Toll-Like Receptor 4 Antagonism: Resatorvid}

Because inflammation is an important event in the development of photocarcinogenesis, some recent research has focused on targeting immunomodulators such as the Toll-like receptors (TLRs). In particular, TLR4 has been thought to be a driver in cutaneous inflammation activating MAPK, AP-1 and NF- $\mathrm{KB}$, as well as the expression of IL-1 $\beta$, IL-6 and TNF- $\alpha$ [70] (Figure 1C).

In the skin, TLR4 expression is upregulated in keratinocytes following UVR exposure [71]. A study that compared normal skin, sun-damaged skin and AKs from the same individuals reported that TLR4 expression was confined to the basal layer of the epidermis in normal skin, whereas in response to sun damage, TLR4 was strongly expressed across several epidermal layers, with thicker and more pronounced detection 
in the AK samples [72]. Therefore, TLR4 antagonism is an emerging target for limiting UV-induced inflammation.

Resatorvid, or TAK-242, is a small-molecule inhibitor that selectively binds to TLR4 and inhibits cellular activity by preventing TLR4 from interacting with adaptor molecules [73]. Resatorvid has been reported to have neuroprotective effects following brain injury [74], and is currently under investigation for its anticarcinogenic properties demonstrated in breast and ovarian cancer cell lines in which TLR4 antagonism reduced epithelialmesenchymal transition and invasion [75].

In a study on irradiated keratinocytes, incubation with resatorvid prevented activation of p38, JNK and Akt. This was accompanied by reductions in AP-1 and NF- $\mathrm{kB}$ activity and IL-6 and IL-8 expression [72]. Notably, the study reported that incubation with resatorvid pre- or post-UVR had similar effects, suggesting that these are not caused by UV absorption but by resatorvid's antagonism of TLR4.

Irradiated hairless mice treated with a topical formulation of resatorvid also demonstrated reduced activity of the MAPKs, AP- 1 and NF- $\mathrm{kB}$ with decreased expression of IL-6, IL-8 and IL-10 [72,76]. When photocarcinogenesis is stimulated experimentally, topical application of resatorvid delayed tumour onset and reduced tumour multiplicity and incidence in hairless mice [76]. Interestingly, this study reported that only when resatorvid was used as a prevention measure-i.e., administered together with UV-and not an intervention treatment-i.e., resatorvid given after UV was terminated - were there reductions in tumourigenesis (Table 2).

Resatorvid has been tested in a clinical trial as a treatment for septic shock. Although it failed to suppress patients' cytokine levels, resatorvid was generally well tolerated [77]. Therefore, resatorvid is a promising candidate for photoprotection, but more studies are needed to elucidate its mechanism of action, determine whether the protective effects can be translated to humans and establish a suitable therapeutic window.

\subsection{Oestrogen Receptor Signalling: Erb041,17ß-Oestradiol and Phytoestrogens}

Another potential pharmaceutical target for skin cancer prevention is the modulation of the oestrogen receptors (ERs) - ER $\alpha$ and ER $\beta$. Both receptors are activated by oestrogen (17 $\beta$-oestradiol) and related oestrogenic compounds, resulting in target gene transcription. Despite sharing ligands, the two receptors often act antagonistically, with ER $\beta$ reportedly functioning as a tumour suppressor to prevent tumour metastasis and proliferation induced by $\mathrm{ER} \alpha[78,79]$. ER $\beta$ specific agonists have been tested in clinical trials to promote the anticarcinogenic effects of ER $\beta$ without stimulating ER $\alpha$ signalling.

Erb-041, or Prinaberel, is an oestrogenic ligand with a similar binding affinity to oestrogen but optimised to selectively bind to ER $\beta$ [80]. A clinical trial monitored Erb-041 intake for its effects on rheumatoid arthritis over a 12-week period, and although treatment failed to show efficacy in patients, the study did report that Erb-041 was well-tolerated and exhibited a good safety profile [81]. In the skin, ER $\beta$ expression is normally confined to the basal layer of the epidermis. This expression is reduced in tumour adjacent skin and lost entirely in skin tissue derived from SCCs. Moreover, ER $\beta$ expression is lost in UV-exposed murine skin [82], further suggesting that ER $\beta$ signalling is a potential target for skin cancer prevention.

One study assessed the effect of Erb-041 in preventing photocarcinogenesis. Treatment with Erb-041 restored ER $\beta$ expression in both irradiated murine skin and cell cultures, and topical application of Erb-041 to hairless mice led to a delay in tumour onset. The mice in this study also exhibited reductions in tumour incidence, multiplicity and volume as well as in carcinoma progression. This was accompanied by a decreased inflammatory response manifesting as reduced leukocyte infiltration, hyperplasia and inflammatory cytokines. Furthermore, Erb-041 application resulted in reduced activation of ERK, p38, $\mathrm{NF}-\mathrm{kB}$ and Akt signalling and decreased expression of proliferation, angiogenesis and epithelial-mesenchymal transition markers [82]. These observations suggest that Erb-041 can prevent UV-induced events (Table 2). 
Other non-specific oestrogenic compounds have also been tested as photoprotectants. For example, $17 \beta$-oestradiol injections reduced UV-induced immunosuppression and associated IL-10 production in male mice [83]. Some phytochemicals also have oestrogenic properties, as described below (Section 3). These natural phytoestrogens share structural similarities with oestrogen and are capable of modulating ER signalling, albeit with lower potency [84]. Phytoestrogens such as genistein, epicatechin and resveratrol exhibit numerous protective effects [85]; the latter two are discussed in Sections 3.1 and 3.2.

Although activation of ER $\beta$ signalling is a potential target for preventing UVR-induced effects, more studies are needed to understand how ER $\beta$ signalling operates photoprotection. As administration of oestrogenic compounds may also result in some side effects, it is possible that the less potent phytoestrogens may be suitable alternatives.

\subsection{Recent Discoveries in Pre-Clinical Studies: Carvedilol and Bucillamine}

Finally, carvedilol and bucillamine have been studied over the past five years as potential photoprotectants.

Carvedilol is a $\beta$-adrenergic receptor ( $\beta$-AR) antagonist that prevents the binding of catecholamines such as nor- and epinephrine to the $\beta$-AR, licenced for treatment of hypertension and heart disease. However, catecholamines also reportedly impact carcinogenesis by affecting DNA repair and APCs [86,87]. As keratinocytes express $\beta$-AR-2 [88], carvedilol was tested in epidermal cells and hairless mice for its potential in photocarcinogenesis prevention.

In vitro studies reported that following carvedilol treatment, irradiated cells exhibited reductions in NF- $\mathrm{KB}$ and AP- 1 activity, $\mathrm{PGE}_{2}$ release and colony formation $[89,90]$, whereas topical application in reconstituted human skin reduced inflammation markers such as COX-2 and TNF- $\alpha$ expression, as well as hyperplasia and apoptosis [91]. Furthermore, carvedilol treatment decreased inflammatory cytokines and CPDs in hairless mice when photocarcinogenesis is stimulated experimentally. These mice also exhibited delays in tumour onset and reduced tumour multiplicity and incidence [90].

Bucillamine is a cysteine-derived compound that contains two thiol groups, which confer significant antioxidant activity. Bucillamine has been used for more than 30 years in Japan and South Korea as a treatment for rheumatoid arthritis and is well tolerated [92], but it is not licenced for use in the European Union.

Bucillamine shares structural similarities with $\mathrm{N}$-acetylcysteine, a proven photoprotectant in hairless mice [93], but it is reportedly even more potent as an antioxidant [94]. Therefore, the photoprotective potential of bucillamine was evaluated. In irradiated keratinocytes and hairless mice, treatment with bucillamine reduced the activation of JNK and caspase 3 [95]. Furthermore, the mice exhibited reductions in dermal oedema, leukocyte infiltration, proliferation and p53 expression $[95,96]$. These results indicate that bucillamine treatment can prevent UV-induced skin damage in hairless mice. Therefore, future studies should investigate its effects on photocarcinogenesis, focusing on whether bucillamine's inherent antioxidant activity can limit the impact of oxidative stress.

To sum up, the use of pharmaceuticals in photoprotection is an evolving field. Whereas previously, much research focused on preventing the induction of COX-2 by implementing specific inhibitors (NSAIDs), recent studies have involved drug repurposing to avoid the expensive and time-consuming clinical trials necessary to evaluate novel pharmaceuticals. In this section, we have discussed a selection of compounds that may not be ready to use as treatments but do highlight events and mechanisms that may be targeted in future studies. In Table 2, we have provided an overview of the seven compounds discussed in this section, their proposed mechanisms and potential (pre-)clinical results in human and mouse studies. 
Table 2. Selected pharmaceuticals that have been tested for photoprotective effects, their proposed mechanisms and, if applicable, (pre-)clinical results.

\begin{tabular}{|c|c|c|c|c|}
\hline Compound & Model & Mechanism of Action & (Pre-)Clinical Results & Ref \\
\hline $17 \beta$-oestradiol & Mice & $\begin{array}{c}\text { Activates ER signalling, and reduces } \\
\text { immunosuppression }\end{array}$ & & [83] \\
\hline Bucillamine & $\begin{array}{l}\text { Hairless mice, } \\
\text { keratinocytes }\end{array}$ & $\begin{array}{l}\text { Reduces proliferation, cell cycle } \\
\text { arrest and apoptosis while } \\
\text { preventing leukocyte infiltration. }\end{array}$ & & {$[95,96]$} \\
\hline Carvedilol & $\begin{array}{l}\text { Hairless mice, epidermal } \\
\text { cells, ex vivo skin }\end{array}$ & $\begin{array}{l}\text { Induces DNA repair while reducing } \\
\text { the inflammatory response via AP-1 } \\
\text { and NF- } \mathrm{KB} \text { inhibition. }\end{array}$ & $\begin{array}{l}\text { Mice: Delays tumour onset } \\
\text { and reduces tumour incidence } \\
\text { and multiplicity. }\end{array}$ & [89-91] \\
\hline Erb-041 & $\begin{array}{l}\text { Hairless mice, } \\
\text { keratinocytes }\end{array}$ & $\begin{array}{l}\text { Activates the ER } \beta \text { receptor which } \\
\text { inhibits proliferation, angiogenesis } \\
\text { and EMT in tumour tissue. Reduces } \\
\text { signal transduction and the } \\
\text { inflammatory response. }\end{array}$ & $\begin{array}{l}\text { Mice: Delays tumour onset, } \\
\text { reduces tumour incidence, } \\
\text { volume and multiplicity and } \\
\text { prevents SCC progression. }\end{array}$ & [82] \\
\hline Metformin & $\begin{array}{l}\text { Hairless mice, } \\
\text { Xenografted (A431) mice, } \\
\text { keratinocytes }\end{array}$ & $\begin{array}{l}\text { Activates AMPK signalling which } \\
\text { facilitates DNA repair, reduces the } \\
\text { inflammatory response and induces } \\
\text { tumour cell apoptosis. }\end{array}$ & $\begin{array}{l}\text { Mice: Delays tumour onset } \\
\text { and reduces tumour incidence } \\
\text { and multiplicity. }\end{array}$ & $\begin{array}{c}{[41,60,} \\
61]\end{array}$ \\
\hline NSAIDs & $\begin{array}{l}\text { AK-affected individuals, } \\
\text { hairless mice }\end{array}$ & $\begin{array}{l}\text { Prevents DNA damage, reduces } \\
\text { COX-2 induction and the } \\
\text { inflammatory response via AP-1 and } \\
\text { NF- } \kappa \text { B inhibition. }\end{array}$ & $\begin{array}{l}\text { Human: Reduces keratinocyte } \\
\text { carcinomas (SCCs and BCCs) } \\
\text { and promotes AK } \\
\text { regression.Mice: Delays } \\
\text { tumour onset and reduces } \\
\text { tumour incidence, progression } \\
\text { and multiplicity. }\end{array}$ & [47-49] \\
\hline Resatorvid & $\begin{array}{l}\text { Hairless mice, } \\
\text { keratinocytes }\end{array}$ & $\begin{array}{l}\text { Inhibits TLR4 signalling which } \\
\text { reduces MAPK, AP-1 and NF-KB } \\
\text { signalling and the } \\
\text { inflammatory response. }\end{array}$ & $\begin{array}{l}\text { Mice: Delays tumour onset } \\
\text { and reduces tumour incidence } \\
\text { and multiplicity. }\end{array}$ & {$[72,76]$} \\
\hline
\end{tabular}

Abbreviations: AK: actinic keratosis, AMPK: AMP-activated protein kinase, AP-1: activator protein 1, BCC: basal cell carcinoma COX-2: cyclooxygenase, ER: oestrogen receptor, EMT: epithelial-mesenchymal transition., MAPK: mitogen-activated protein kinase, NSAIDs: non-steroidal anti-inflammatory drugs, SCC: squamous cell carcinoma, TLR4: Toll-like receptor 4.

\section{Dietary and Non-Dietary Phytochemicals}

Whereas the use of pharmaceuticals in photoprotection has primarily focused on anti-inflammatory drugs and possible repositioning strategies, the use of plant-derived compounds-referred to as phytochemicals-has shown great potential for photoprotection. Phytochemicals are diverse compounds that can modulate oxidative stress, inflammation, signal transduction and other pathways that contribute to photocarcinogenesis [97]. Polyphenols are particularly common photoprotective phytochemicals that act as antioxidants to prevent ROS formation.

\subsection{Green Tea and Polyphenols}

The polyphenols from green tea (Camellia sinensis) have been studied intensively for their effects on photocarcinogenesis. The focus has been on epigallocatechin-3-gallate (EGCG) - the most abundant polyphenol found in green tea-because it exhibits the greatest activity [98]. Incubation with green tea polyphenols (GTPs) increases antioxidant activity and reduces the release of ROS in vitro [99,100]. Furthermore, GTPs reduce the phosphorylation and activation of MAPKs and NF- $\mathrm{KB}[100,101]$.

Similar effects have been reported in hairless mice in which GTP administration also led to reductions in tumour incidence, multiplicity and malignant transformation, as well as delays in tumour onset [102,103]. Mice receiving oral administration of GTPs also exhibited reduced levels of inflammation and $\mathrm{PGE}_{2}$ and decreased expression of IL-1 $\beta$, 
IL-6, TNF- $\alpha$ and COX-2 [103]. Moreover, topical GTP application reduced UV-induced oedema, hyperplasia and infiltration of leukocytes (Table 3) [102].

Mechanisms have been proposed to explain these protective effects. EGCG-treated irradiated mice exhibited decreased levels of DNA hypomethylation due to downregulation of DNA methylases [102], which otherwise can mediate malignant transformation via transcriptional changes [104]. GTP may also stimulate photoprotection via IL-12, which counteracts DNA damage by increasing NER-gene expression (Figure 2) [105]. EGCG induced IL-12 in keratinocytes, whereas subsequent addition of anti-IL-12 antibodies eliminated the protective effects of EGCG [106]. Similarly, GTP treatment has less effect on IL-12-KO mice than on wild-type mice [103], indicating that IL-12 is important for this protective effect.

GTPs have been tested both topically and orally in human trials, with conflicting results. Topical application of GTPs provided protection against UV-induced DNA damage and erythemal response [107], whereas oral administration of $800 \mathrm{mg}$ or $1080 \mathrm{mg}$ of EGCG provided no protection $[108,109]$. Similar results were reported for oral administration of $540 \mathrm{mg}$ GTPs and $50 \mathrm{mg}$ vitamin C over a period of three months [110]. This discrepancy is surprising as GTPs reportedly have no significant UV-absorption that could potentiate its topical effect.

Despite the promising in vivo studies, the results from human trials were disappointing. Furthermore, GTPs are prone to oxidation and degradation [111] and have a half-life of only five hours in human circulation [112], restricting effective administration and storage.

\subsection{Grapes and Related Polyphenols: Proanthocyanidins, Resveratrol and Pterostilbene}

Grapes and their seeds contain polyphenols, such as proanthocyanidins and oestrogenic stilbenes such as resveratrol. Incubating various skin cell models with grape extracts has yielded promising results, including reductions in DNA damage, inflammation and oxidative stress [113], and several studies have explored these protective effects in the hairless mouse model [114-118].

Dietary supplementation to mice undergoing UVR with grapes or grapeseed extracts had anticarcinogenic effects. These mice exhibited increased antioxidant capacities, manifesting as decreases in LPO, protein carbonylation and ROS [116]. MAPK and NF- $\mathrm{kB}$ activation were also impaired following oral intake. This was accompanied by reductions in UV-induced inflammation, demonstrated by decreases in cutaneous leukocyte infiltration, $\mathrm{PGE}_{2}$ release and expression of COX-2 as well as the inflammatory cytokines IL-1 $\beta$, IL-6 and TNF- $\alpha$ [114]. IL-10 expression was also reduced, indicating decreased immunosuppression [117].

Grape constituents may also counteract tumour formation and development. Providing hairless mice with grape-based supplements reduced proliferation markers and CPD formation facilitated by increased NER-genes transcription $[114,118]$. This was reflected by reductions in tumour incidence, multiplicity, size and progression [114,115].

Similar effects have recently been observed in human trials. For example, Oak et al. reported that a daily intake of $75 \mathrm{~g}$ freeze-dried grape supplement-containing both proanthocyanindins and resveratrol-for 14 days led to an increase in mean minimal erythema dose (MED) pre- and post-intervention (173.1 and $267.6 \mathrm{~J} / \mathrm{m}^{2}$, respectively) [119]. Oak et al. also demonstrated reductions in epidermal apoptosis, DNA damage and downregulation of inflammatory mediators such as IL-1 $\beta$, IL- 8 and IL-22 following intake of a dietary grape supplement [120].

These reported effects of grape constituents suggest that pterostilbene may also have promising protective effects, although few relevant studies have specifically investigated photoprotection. Pterostilbene is a dimethylether analogue of resveratrol and reportedly has 3-4 times the bioavailability [121]. Irradiated hairless mice treated with a topical pterostilbene cream exhibited reduced signs of skin damage such as wrinkling and hyperplasia. The mice also had increased antioxidant capacity with subsequent decreases in LPO, protein carbonylation and oxidative DNA lesions. Finally, the study concluded that the 
application of pterostilbene but not resveratrol reduced tumour incidence in these mice (Table 3) [122].

Based on these results, more research should focus on elucidating the effect of grapes in human photoprotection. Furthermore, studies should explore whether the increased bioavailability of pterostilbene and the improved in vivo results can be translated into clinical results to provide an additional avenue for protection.

\subsection{Polypodium Leucotomos}

Polypodium leucotomos (PL) is a fern plant with a high content of polyphenols native to Central and South America [123]. An aqueous extract of the leaves containing these phenols is sold as a dietary supplement under the tradename Fernblock ${ }^{\circledR}$. Fernblock ${ }^{\circledR}$ and other extracts of PL have exhibited photoprotective properties both in vitro and in vivo, as well as in clinical trials.

The mechanism of photoprotection has been investigated extensively and involves significant antioxidant activity. PL provided protection against ROS formation and LPO in vitro [124,125], whereas oral administration of PL to hairless mice reportedly increased antioxidant enzyme capacity and prevented the formation of oxidative DNA lesions [126,127]. These mice also exhibited reductions in CPD formation and proliferation markers with increased p53 expression.

PL had immunomodulatory activity and decreased transcriptional activation of NF- $\kappa \mathrm{B}$ and AP-1, as well as expression of TNF- $\alpha$ in vitro [128]. In hairless mice, PL counteracted COX-2 induction and infiltration of leukocytes following UVR exposure [127]. It also prevented immunosuppression [129], as demonstrated by the inhibition of photoisomerisation and photodecomposition of trans-UCA [124], as well as inhibition of Langerhans cell depletion in hairless rats [130].

Oral administration of PL to hairless mice significantly delayed tumour onset and decreased the incidence of AKs following UVR exposure [131]. Decreased tumour incidence was also reported in a similar study (Table 3) [132].

In healthy volunteers, a dietary supplement $(1080 \mathrm{mg})$ or topical application $(10 \%)$ of PL prior to UVR exposure significantly increased the $\operatorname{MED}\left(80,98\right.$ and $34 \mathrm{~mJ} / \mathrm{cm}^{2}$ for dietary administration, topical administration and untreated controls, respectively) and prevented depletion of Langerhans cells [133]. Studies with a lower dietary dose of $240 \mathrm{mg}$ reported similar protective effects including reductions in erythema and oedema $[134,135]$, sunburn cell formation, CPDs [134-136], expression of COX-2 and proliferation markers [136], as well as inhibition of Langerhans cell depletion [134].

Furthermore, $240 \mathrm{mg}$ of PL taken twice a day for two months provided effective protection against sun damage evaluated by MED and erythema with no adverse side effects [137]. Overall, PL is a promising photoprotectant that decreases tumourigenesis in mouse models and counteracts harmful acute UV-induced effects in humans. However, further studies are needed to elucidate the long-term effects of PL on skin cancer development.

\subsection{Berries: Pomegranate, Raspberries and Blackberries}

Because of the potential impact of polyphenols in photoprotection, the properties of berries also warrant investigation. Berries such as pomegranate, raspberries and blackberries have very high polyphenolic contents and are easy to purchase.

Among these three, the anticarcinogenic properties of pomegranate have been studied most extensively. Pomegranates from the Punica granatum tree contain antioxidants that are more potent than those from sources such as red wine and green tea [138]. In hairless mice, a dietary supplement of pomegranate extract decreased MAPK signalling, inhibited NF- $\kappa B$ activity and led to reductions in the inflammatory response, including decreased COX-2 expression and leukocyte infiltration [139]. Furthermore, oral administration to mice reduced CPDs, oxidative DNA lesions and other markers of oxidative stress [140].

When photocarcinogenesis is stimulated experimentally, pomegranate-fed mice exhibited a decreased incidence of SCC s with reductions in both p53 expression and prolifera- 
tion [141]. In human studies, intake of pomegranate over 12 weeks provided protection against UVR, as shown by increases in MED from baseline to post-treatment [142].

Although there have been no clinical trials, raspberries also have great potential as a photoprotectant. Hairless mice treated topically with a black raspberry extract following UVR exposure exhibited decreases in tumour multiplicity and size. This was accompanied by reductions in the number of 8-oxo-Gua lesions and in p53 expression, as well as a reduced inflammatory response, which was indicated by decreased neutrophil activation and oedema [143]. Recent studies have also shown that red raspberries exhibit promising topical photoprotectant activity. Albeit no data on tumour formation, irradiated mice treated with a red raspberry extract demonstrated reductions in erythemal response, p38, AP-1 and NF- $\mathrm{kB}$ activity, together with decreased COX-2 expression. The antioxidant capacity was also increased in these mice, possibly via nuclear factor erythroid 2-related factor (Nrf-2) activation, which induces transcription of antioxidant-response genes and decreases 8-oxo-Gua lesions and protein carbonylation [144], mimicking results reported in vitro [145].

Finally, blackberries and one of their polyphenols, cyanidin-3-glucoside, have displayed promising photoprotective characteristics in vivo. Topical application of blackberry extract or the polyphenol to hairless mice undergoing UVR showed reductions in both the inflammatory and oxidative stress responses. These mice exhibited reductions in LPO and oxidative DNA lesions, as well as decreased oedema, hyperplasia and leukocyte infiltration. Reductions in MAPK signalling and NF- $\mathrm{kB}$ activity were also reported, together with subsequent decreases in PGE 2 release and expression of iNOS, IL-6 and TNF- $\alpha$ (Table 3) $[146,147]$.

Although some of these studies focused on topical application, the widespread availability of these berries is ideal for oral photoprotection. However, further studies are needed to confirm the protective potential of berries: extensive mouse studies should be used to elucidate protective mechanisms and clinical trials are needed to investigate whether berries can prevent KCs in humans.

\subsection{Cocoa Flavanols}

Polyphenolic compounds can also be found in cocoa as so-called cocoa flavanols. Although chocolate and other cocoa-containing products may have a high cocoa content, the flavanols are often destroyed in processing steps before the final products are generated. Nevertheless, the potential of cocoa extracts in epidermal health has been suggested by pointing to effects such as ROS scavenging, prevention of MAPK and NF- $\mathrm{kB}$ activation and inhibition of COX-2 induction [148,149].

Because similar pathways contribute to KC development, the effect of cocoa extract was tested in hairless mice when photocarcinogenesis was stimulated experimentally. Following oral intake of cocoa extract, these mice had fewer wrinkles and MMP-1 expression was downregulated [150]. Irradiated mice given cocoa extract also exhibited a lower incidence of invasive SCCs, as well as decreases in mutated p53 expression and $\mathrm{PGE}_{2}$ release [141], indicating increased protection against UV-induced events and carcinogenesis.

Cocoa extract has also proved beneficial in humans. In 2006, a clinical trial spanning over 12 weeks reported that a daily intake of $329 \mathrm{mg}$ cocoa flavanols reduced UV-induced erythema by $25 \%$, whereas a lower intake $(27 \mathrm{mg})$ did not [151]. Other studies exploring shorter and longer intervention periods ( 1 and 24 weeks, respectively) had similar outcomes, resulting in increases in MED [150,152]. However, two studies investigated the effects of a higher dose ( $600 \mathrm{mg}$ ) over 12 weeks, and only one of these studies found a protective effect $[153,154]$, suggesting that more research is needed to clarify the photoprotective effects of cocoa flavanols.

As described in this section, dietary and non-dietary phytochemicals have enormous potential for photoprotection. Pre-clinical and human trials have shown that these compounds have antioxidant, anti-inflammatory and anti-carcinogenic effects in subjects exposed to UVR (Table 3). 
In contrast to pharmaceuticals, which are expensive and may have adverse side effects, phytochemicals are widely available and may be readily included in the daily diet. Furthermore, while phytochemical intake at higher concentrations may have some side effects, they are not as severe as what is demonstrated with certain pharmaceuticals. However, because some polyphenolic compounds absorb UVR, observed effects may be due to a sunscreen effect leaving oral administration inefficient [155]. Therefore, more research is needed to evaluate the use of phytochemicals in long-term systemic photoprevention. These studies should focus on dosing, delivery and effectiveness to optimise the protective potential.

Table 3. Selected phytochemicals that have been tested for photoprotective effects, their proposed mechanisms and, if applicable, (pre-)clinical results.

\begin{tabular}{|c|c|c|c|c|}
\hline Compound & Model & Mechanism of Action & (Pre-)Clinical Results & Ref \\
\hline Blackberries & $\begin{array}{l}\text { Hairless mice, } \\
\text { keratinocytes, } \\
\text { ex vivo skin }\end{array}$ & $\begin{array}{l}\text { Reduces oxidative stress and } \\
\text { the inflammatory response. }\end{array}$ & & {$[146,147]$} \\
\hline Cocoa flavanols & $\begin{array}{l}\text { Healthy volunteers, } \\
\text { hairless mice }\end{array}$ & $\begin{array}{l}\text { Reduces mutagenesis of p53, } \\
\text { inflammatory markers and } \\
\text { degradation of the } \\
\text { extracellular matrix. }\end{array}$ & Mice: Reduces invasive SCCs. & {$[141,150-154]$} \\
\hline Grape seeds & $\begin{array}{l}\text { Healthy volunteers, } \\
\text { hairless mice, } \\
\text { keratinocytes }\end{array}$ & $\begin{array}{l}\text { Increases antioxidant activity, } \\
\text { reduces the inflammatory } \\
\text { response and proliferation and } \\
\text { promotes DNA repair. }\end{array}$ & $\begin{array}{l}\text { Mice: Reduces tumour } \\
\text { incidence, size, multiplicity } \\
\text { and progression. }\end{array}$ & [114-120] \\
\hline Green tea & $\begin{array}{l}\text { Healthy volunteers, } \\
\text { hairless mice, } \\
\text { keratinocytes }\end{array}$ & $\begin{array}{l}\text { Prevents DNA } \\
\text { hypomethylation, stimulates } \\
\text { IL-12 (facilitating DNA repair) } \\
\text { and reduces the inflammatory } \\
\text { response and oxidative stress. }\end{array}$ & $\begin{array}{l}\text { Mice: Delays tumour onset } \\
\text { and reduces tumour incidence, } \\
\text { multiplicity and progression. }\end{array}$ & {$[99-103,106]$} \\
\hline $\begin{array}{l}\text { Polypodium } \\
\text { leucotomos }\end{array}$ & $\begin{array}{l}\text { Healthy volunteers, } \\
\text { hairless mice, } \\
\text { keratinocytes, } \\
\text { fibroblasts }\end{array}$ & $\begin{array}{l}\text { Prevents photoisomerisation of } \\
\text { trans-UCA (counteracting } \\
\text { immunosuppression) and } \\
\text { increases antioxidant activity. } \\
\text { Reduces DNA lesions, } \\
\text { proliferation and the } \\
\text { inflammatory response. }\end{array}$ & $\begin{array}{l}\text { Mice: Reduces AK occurrence, } \\
\text { delays tumour onset and } \\
\text { reduces tumour incidence. }\end{array}$ & [124-136] \\
\hline Pomegranate & $\begin{array}{l}\text { Healthy volunteers, } \\
\text { hairless mice }\end{array}$ & $\begin{array}{c}\text { Reduces DNA lesions, } \\
\text { oxidative damage, the } \\
\text { inflammatory response and } \\
\text { signal transduction. }\end{array}$ & $\begin{array}{l}\text { Mice: Reduces SCC } \\
\text { occurrence. }\end{array}$ & [139-142] \\
\hline Pterostilbene & $\begin{array}{l}\text { Hairless mice, } \\
\text { keratinocytes }\end{array}$ & $\begin{array}{l}\text { Reduces oxidative stress via } \\
\text { increased antioxidant capacity. }\end{array}$ & $\begin{array}{l}\text { Mice: Reduces tumour } \\
\text { incidence and multiplicity. }\end{array}$ & [122] \\
\hline Raspberries & $\begin{array}{l}\text { Hairless mice, } \\
\text { fibroblasts }\end{array}$ & $\begin{array}{l}\text { Reduces oxidative DNA } \\
\text { damage and stress via } \\
\text { increased antioxidant activity. } \\
\text { Reduces the inflammatory } \\
\text { response and AP-1 and } \\
\text { NF-kB activity. }\end{array}$ & $\begin{array}{l}\text { Mice: Reduces tumour size } \\
\text { and multiplicity. }\end{array}$ & [143-145] \\
\hline
\end{tabular}

Abbreviations: AK: actinic keratosis, AP-1: activator protein 1, IL: interleukin, SCC: squamous cell carcinoma, UCA: urocanic acid.

\section{Vitamins and Derived Compounds}

\subsection{Vitamin A: The Retinoids}

Vitamin A represents a class of naturally occurring or synthetically produced compounds that share structural or functional properties and are commonly referred to as retinoids. Dietary sources of vitamin A include plant products containing provitamin A carotenoids [156] or animal products such as dairy products, eggs and liver in which vita- 
min A is present as retinol, retinal, retinyl esters and retinoic acid (RA) $[157,158]$. Because the photoprotective potential of carotenoids has been explored in other reviews [159], the following description will focus on the latter group.

In vitro studies have shown that retinoids have antioxidant activity that prevents ROS formation, in part due to restoration of Nrf2 [160]. Furthermore, retinoids exhibit anti-inflammatory properties by reducing AP-1 activity $[161,162]$ and TNF- $\alpha$ expression [163,164]. However, because topical retinoid treatment can cause skin irritation [165,166], the elicited inflammatory responses must be considered in their specific contexts.

Whereas topical application of retinoids protects against DNA damage and apoptosis in hairless mice [167], the effects on photocarcinogenesis reportedly vary and remain controversial. Two separate experiments from the same group led by Epstein et al. showcased these opposing effects of RA, reporting stimulation of photocarcinogenesis in one study [168] but inhibition in another [169]. A similar paradox has been reported by other groups, with stimulatory $[166,170,171]$, inhibitory [172], and no effect on photocarcinogenesis in hairless mice treated with RA all being described [173]. No mechanism has been suggested that can resolve these conflicting results.

Consequently, few human studies have been performed. One study reported that the application of a $2 \%$ retinyl ester cream protected against thymine dimers and erythema in healthy volunteers 24 hours after UVR treatment [174]. However, topical application of a $0.05 \%$ all-trans RA cream for eight days had no effect on MED [175]. Although this discrepancy may be caused by differences in the retinoic compounds or their concentrations, it may also reflect the pattern observed in the mouse studies.

Despite this, a recent cohort study reported that increased dietary intake of retinol led to a decreased risk of SCC [176]. Similarly, in psoriasis patients exposed to psoralen-UVA, systemic retinoid use was associated with a significant reduction in SCC risk [177]. In a trial focusing on subjects with a history of AKs, a dietary supplement of 25,000 IU retinol over five years protected against SCC but not BCC incidence (Table 4) [178]. However, the same group reported a lack of effect in high-risk subjects with a history of KCs [179]. Taken together, these results indicate that we still do not know enough about how retinoids function and whether they can consistently provide photoprotection.

\subsection{Vitamin B3: Nicotinamide}

Vitamin $B_{3}$ represents a family of water-soluble compounds with similar structures that include nicotinamide, nicotinic acid and nicotinamide riboside. These are found in fish, meat and wheat, with smaller quantities present in vegetables. Vitamin $\mathrm{B}_{3}$ compounds act as precursors for the cofactor nicotinamide adenine dinucleotide $\left(\mathrm{NAD}^{+}\right)$which is involved in ATP metabolism [180-182]. NAD ${ }^{+}$deficiency increases the skin's sensitivity to UVR exposure by reducing genomic stability and preventing DNA repair [183]. Therefore, replenishing $\mathrm{NAD}^{+}$precursors is a potential strategy in cancer prevention.

$\mathrm{NAD}^{+}$acts as a substrate for poly ADP-ribose polymerase-1 (PARP-1) and the sirtuin proteins that regulate DNA repair and genomic stability [184,185]. Incubation of irradiated keratinocytes with nicotinamide enhanced DNA repair and reduced photolesions [186]. Furthermore, pre-treatment also prevented UV-induced inflammation in keratinocytes by reducing the expression of IL-6, IL-10, TNF- $\alpha$ and COX-2 [187,188].

Gensler et al. have described the effect of nicotinamide in mouse models and found that topical and systemic administration resulted in decreased tumour incidence in irradiated BALB/c mice $[189,190]$. Moreover, these mice exhibited reductions in tumour development, tumour multiplicity and UV-induced immunosuppression.

Topical application of a $5 \%$ nicotinamide cream also reduced immunosuppression in healthy human volunteers [191,192]. As an oral delivery study reported similar protective results [193], with no effect on MED following topical application [191], the effects of nicotinamide are likely caused by protection against UV-induced events rather than sunscreening (Table 4). 
The effects of treating sun-damaged individuals with nicotinamide were investigated in a phase II double-blinded randomised controlled trial. In volunteers with $\geq 4$ palpable AKs, $500 \mathrm{mg}$ dietary supplement reduced the mean AK count over a period of four months (21.6 vs. 34.8 in the control group) [194]. Similar effects were reported over one year in a phase III trial involving high-risk subjects, with dietary supplements reducing the rate of new KCs (1.8 per person in nicotinamide-treated subjects vs. 2.4 in control subjects) and SCCs (0.5 vs. 0.7 per person, respectively) [195]. This trial reported few adverse effects and no additional effect at higher doses, suggesting that $500 \mathrm{mg}$ is a safe and effective dose. However, no beneficial effects were observed on recurrent carcinomas or following treatment discontinuation [195].

The phase III trial was notable for an increase in infections among the treated group and significant differences in the numbers of skin and mucocutaneous infections [196]. Although the authors accepted that all adverse effects should be considered, they also noted that nicotinamide reportedly increases the clearance of skin infections [197,198]. Nevertheless, Yélamos et al. noted that while an overall reduction in $\mathrm{KC}$ rates was observed following nicotinamide intake, the more aggressive types of SCCs and BCCs apparently increased [199].

Therefore, although nicotinamide has protective effects in human studies, additional trials with a focus on patient follow-up and the differences among and subtypes will be necessary to address these concerns.

\subsection{Vitamin C}

Vitamin C is a key antioxidant found in the skin where it plays a role in keratinocyte viability and maintenance of the epidermal barrier [200]. Vitamin C can be synthesised from D-glucose in plants and almost all non-primates [201], whereas humans can no longer produce the active enzyme required for this process. Therefore, humans obtain vitamin $\mathrm{C}$ from their diet.

The antioxidant properties of vitamin $C$ are well established. In keratinocytes, treatment with vitamin $C$ reduced ROS formation [202], oxidative DNA damage [203] and LPO, simultaneously preventing glutathione depletion [204]. Treatment with vitamin C also affects inflammatory responses, leading to decreased expression and release of IL- $1 \alpha$, IL-6, IL-8 and TNF- $\alpha$ [202,204,205], while also preventing apoptosis and MAPK activation (Table 4) [202,206].

Despite these effects and its role as an antioxidant, the photoprotective potential of vitamin $C$ is less clear in in vivo studies. In a study performed in 1982, dietary supplementation of vitamin $\mathrm{C}$ given to hairless mice led to a delay in UV-induced tumour onset and decreased tumour incidence [207]. A second study, performed nine years later, confirmed these observations [208]. However, in 2005, a study involving a similar set-up observed an increase in UV-induced tumour multiplicity [93], indicating some uncertainty regarding the effect of vitamin $C$ when more complex models are used.

Furthermore, few clinical trials have investigated the photoprotective effects of vitamin C. In a study performed in 2002, $500 \mathrm{mg}$ oral supplement of vitamin C over an eight-week period had no effect on the UV-induced erythemal response measured [209]. Studies exploring higher doses of $2 \mathrm{~g}$ and $3 \mathrm{~g}$-albeit over shorter periods (7 and 50 days, respectively) - also reported no significant effects [210,211]. Topical application of a 5\% cream also offered no protection in healthy volunteers [212,213], and cohort studies lasting more than ten years have found no evidence that vitamin $C$ intake decreases the incidence of BCCs and SCCs [214,215].

Because vitamin $C$ alone does not appear to provide photoprotection in vivo, the focus of research has shifted to investigating vitamin $C$ combined with other compounds. Combining vitamins $\mathrm{C}$ and $\mathrm{E}$ has produced promising clinical results and is further described in Section 4.5 [211,216,217]. Similarly, a topical formulation of vitamin C, ferulic acid and the phenolic compound phloretin conferred protection against UV-induced erythema, apoptotic sunburn-cell production and thymine dimer formation in healthy volunteers [218], indicating that vitamin $\mathrm{C}$ in synergy with other compounds may provide sufficient protection. 


\subsection{Vitamin $D_{3}$}

The epidermis is the primary source of vitamin $\mathrm{D}_{3}$ (cholecalciferol). Vitamin $\mathrm{D}_{3}$ is a fat-soluble steroid hormone primarily obtained by de novo synthesis in the skin with only a fraction obtained through the diet. In the skin, a cholesterol precursor is converted to pre-vitamin $\mathrm{D}_{3}$ and then to active vitamin $\mathrm{D}_{3}\left(1,25(\mathrm{OH})_{2} \mathrm{D}\right)$ in a reaction catalysed by sunlight [219]. Despite this reliance on a major source of carcinogenesis, increasing evidence suggests that vitamin $\mathrm{D}_{3}$ may act as a tumour suppressor via crosstalk with p53 [220].

Expression of p53 is increased in irradiated keratinocytes following $1,25(\mathrm{OH})_{2} \mathrm{D}$ treatment [221,222]. Incubation with $1,25(\mathrm{OH})_{2} \mathrm{D}$ or analogues with low calcaemic activity also protected against cell death and CPD formation [223,224], while $1,25(\mathrm{OH})_{2} \mathrm{D}$ and a non-genomic analogue provided protection against CPDs and 8-oxo-Gua lesions in ex vivo studies [225].

In in vivo studies, topical administration of $1,25(\mathrm{OH})_{2} \mathrm{D}$, as well as low calcaemic and non-genomic analogues, protected hairless mice against immunosuppression and DNA damage, inducing p53 expression to promote cell cycle arrest [222,226]. In addition, $1,25(\mathrm{OH})_{2} \mathrm{D}$ and the non-genomic analogue reduced photocarcinogenesis, decreasing tumour incidence and multiplicity as well as reducing the number of tumours that progressed to SCCs [222]. Another study demonstrated similar protective effects but by week 26 , the $1,25(\mathrm{OH})_{2}$ D-treated mice exhibited more than $20 \%$ weight loss, reportedly due to chronic hypercalcaemia [227]. This side effect was also noted in the aforementioned study and was addressed by decreasing the concentration of $1,25(\mathrm{OH})_{2} \mathrm{D}$ administered [226].

A recent clinical trial investigated the effect of vitamin $\mathrm{D}_{3}$ as a photoprotectant in human studies. This study included doses such as 50,000, 100,000 and 200,000 IU, with only the latter reportedly capable of protecting against UVR-induced oedema and decreasing TNF- $\alpha$ expression. A clustering analysis identified one distinct cluster primarily containing participants who received the highest dose. The participants in this cluster had increased serum vitamin $\mathrm{D}_{3}$, reduced erythema and a distinct gene profile when compared to another group of participants, many of whom received placebo [228]. Vitamin $\mathrm{D}_{3}$ protected against upregulation of pro-inflammatory mediators and induced genes involved in skin barrier repair, enhancing photoprotection (Table 4). Furthermore, this study reported no adverse effects or increases in serum calcium, suggesting that the vitamin $\mathrm{D}_{3}$ dose used was safe for testing in future studies.

The mechanism underlying vitamin $\mathrm{D}_{3}$ photoprotection is not entirely clear. Mice, where the vitamin D receptor (VDR) has been knocked out, are more prone to photocarcinogenesis [229]. Because VDRs with mutations in the DNA binding domain are still capable of stimulating photoprotection [230], this may be mediated through a non-genomic pathway. Consequently, although vitamin $\mathrm{D}_{3}$ has protective effects, further studies are needed to determine its mechanism of action and effect on human carcinogenesis.

\subsection{Vitamin E: $\alpha$-Tocopherol}

Vitamin E covers a class of fat-soluble compounds, the tocopherols and tocotrienols. $\alpha$-tocopherol has the greatest biological activity and is the most abundant form of vitamin E in the skin. Plants can produce vitamin E to protect against sunlight, whereas humans cannot and therefore rely on leafy greens, vegetables and nuts to provide vitamin E through the diet [231]. Similar to vitamin C, vitamin E intake had no protective effect on KC incidence [214,215]. Despite this, vitamin E did exhibit several noteworthy photoprotective properties.

Vitamin $\mathrm{E}$ functions as an antioxidant by scavenging radicals to reduce the damaging effects of oxidative stress [232-234]. Incubation with vitamin E protected keratinocytes against UV-induced cytotoxicity, apoptosis and NF- $\mathrm{kB}$ activation [235,236] Moreover, incubation with vitamin E before or after UVR exposure reduced the appearance of CPDs and oxidative DNA lesions [233], indicating that these observations were not solely attributed to a sun-screening effect (Table 4). 
In hairless mice, topical application of vitamin E reduced UV-induced erythema and oedema [237,238], as well as immunosuppression and tumour incidence [239]. Similarly, dietary vitamin $\mathrm{E}$ supplementation resulted in delayed tumour onset and reductions in tumour multiplicity and size. These mice also exhibited decreased proliferation and oxidative stress markers such as 8-oxo-Gua lesions [240]. However, a more recent study performed in 2013, reported contrasting effects with a topical vitamin E cream increasing tumour formation and proliferation, DNA damage and angiogenesis [241].

One clinical trial reported that 400-IU vitamin E dietary supplementation over a sixmonth period did not significantly change MED or sunburn-cell formation [242]. A shorter trial with the same dose over an eight-week period did not report any protective effects for vitamin E either [243].

Although neither vitamin $C$ nor E showed significant photoprotection in human studies, combining the two vitamins has promising effects [244]. Adding ferulic acid to a combined preparation of topically applied vitamins $\mathrm{C}$ and $\mathrm{E}$ improves the stability and doubles the photoprotective capacity of the formulation when applied to pigskin, as measured by thymine dimer formation, erythema and apoptosis [245]. In a clinical trial spanning eight days, dietary supplementation of vitamins C and E increased MED (median of $80 \mathrm{~mJ} / \mathrm{cm}^{2}$ before supplementation to $96.5 \mathrm{~mJ} / \mathrm{cm}^{2}$ after eight days) [217]. Similar increases in MED, as well as reduced thymine dimer formation, were observed in longer trials with no effect for the vitamins separately [211,216]. Overall, these results indicate that vitamins $\mathrm{C}$ and $\mathrm{E}$ can act synergistically to protect against UVR exposure.

Table 4. Selected vitamins and derivates that have been tested for photoprotective effects, their proposed mechanisms and, if applicable, (pre-)clinical results.

\begin{tabular}{|c|c|c|c|c|}
\hline Compound & Model & Mechanism of Action & (Pre-)Clinical Results & Ref \\
\hline $\begin{array}{l}\text { Vitamin A: } \\
\text { Retinoids }\end{array}$ & $\begin{array}{l}\text { AK- and KC-affected } \\
\text { patients, healthy } \\
\text { volunteers, hairless } \\
\text { mice, fibroblasts }\end{array}$ & $\begin{array}{l}\text { Reduces DNA damage and the } \\
\text { inflammatory response via AP-1 } \\
\text { and NF- } \mathrm{B} \text { B inhibition. Reduces } \\
\text { oxidative stress by inducing Nrf2. }\end{array}$ & $\begin{array}{l}\text { Human: Reduces } \\
\text { SCC risk*. } \\
\text { Mice: Delays tumour } \\
\text { onset and reduces } \\
\text { tumour incidence **. }\end{array}$ & $\begin{array}{c}{[160-164,167,169,} \\
172,174,177,178]\end{array}$ \\
\hline $\begin{array}{l}\text { Vitamin } \mathrm{B}_{3}: \\
\text { Nicotinamide }\end{array}$ & $\begin{array}{l}\text { AK-affected and } \\
\text { high-risk patients, } \\
\text { hairless mice, } \\
\text { keratinocytes }\end{array}$ & $\begin{array}{l}\text { Induces DNA repair by acting as } \\
\text { an } \mathrm{NAD}^{+} \text {precursor. Reduces } \\
\text { immunosuppression and the } \\
\text { inflammatory response. }\end{array}$ & $\begin{array}{l}\text { Human: Reduces AK } \\
\text { occurrence and rate of } \\
\text { new KCs and SCCs } \\
\text { Mice: Reduces tumour } \\
\text { incidence and } \\
\text { multiplicity. }\end{array}$ & [186-195] \\
\hline Vitamin C & $\begin{array}{l}\text { Healthy volunteers, } \\
\text { hairless mice, } \\
\text { keratinocytes }\end{array}$ & $\begin{array}{l}\text { Increases antioxidant capacity and } \\
\text { reduces ROS formation, DNA } \\
\text { lesions and LPO. Reduces the } \\
\text { inflammatory response. }\end{array}$ & $\begin{array}{l}\text { Mice: Delays tumour } \\
\text { onset and reduces } \\
\text { tumour incidence }{ }^{* *} \text {. }\end{array}$ & [202-208] \\
\hline Vitamin $D_{3}$ & $\begin{array}{l}\text { Healthy volunteers, } \\
\text { hairless mice, } \\
\text { keratinocytes, } \\
\text { ex vivo skin }\end{array}$ & $\begin{array}{l}\text { Non-genomic signalling via the } \\
\text { VDR facilitates protection against } \\
\text { DNA lesions and cell cycle arrest } \\
\text { while reducing } \\
\text { immunosuppression. }\end{array}$ & $\begin{array}{l}\text { Mice: Reduces tumour } \\
\text { incidence, multiplicity } \\
\text { and progression. }\end{array}$ & [221-227] \\
\hline $\begin{array}{c}\text { Vitamin E: } \\
\alpha \text {-tocopherol }\end{array}$ & $\begin{array}{l}\text { Healthy volunteers, } \\
\text { hairless mice, } \\
\text { keratinocytes }\end{array}$ & $\begin{array}{l}\text { Prevents oxidative damage by } \\
\text { increasing antioxidant activity. } \\
\text { Reduces DNA damage, } \\
\text { immunosuppression, proliferation, } \\
\text { apoptosis and the inflammatory } \\
\text { response via AP-1 and } \\
\text { NF-kB inhibition. }\end{array}$ & $\begin{array}{l}\text { Mice: Delays tumour } \\
\text { onset and reduces } \\
\text { tumour incidence, } \\
\text { multiplicity and size }{ }^{* *} \text {. }\end{array}$ & [233-240] \\
\hline
\end{tabular}

*: inconsistent results, ${ }^{* *}$ : contrasting results have been reported (retinoids [166,170,171]; vitamin C [93]; $\alpha$-tocopherol [241]). Abbreviations: AK: actinic keratosis, AP-1: activator protein 1, KC: keratinocyte carcinoma, LPO: lipid peroxidation, NRF2: nuclear factor erythroid 2-related factor 2, ROS: reactive oxygen species, SCC: squamous cell carcinoma, VDR: vitamin D receptor. 


\section{Perspectives and Concluding Remarks}

When sun-avoidant behaviour, protective clothing and sunscreens are used insufficiently to prevent $\mathrm{KCs}$, oral photoprotection presents a promising alternative or supplement. Instead of blocking the absorption of UV-rays, dietary intake of protective compounds focuses on preventing and countering UV-induced events that stimulate photocarcinogenesis (Figures 1 and 2). Using oral photoprotectants in addition to sunscreen will increase the protection against UVR-induced effects.

Drug repurposing provides a promising avenue for systemic photoprotection, with varying degree of success in pre-clinical trials (Table 2). However, applying these findings to clinical trials may be difficult as data obtained from studies in unrelated conditions may not be relevant for evaluating the efficacy and safety of treatments to prevent photocarcinogenesis in humans. Therefore, new investigations are needed to identify therapeutic windows in which photoprotection is effective.

Phytochemicals are promising photoprotectants. Their protective effects (Table 4), low toxicity and widespread availability make them ideal candidates for systemic photoprotection. Nevertheless, not all compounds are effective via ingestion, and phytochemicals may require extraction, purification and concentration to generate effective photoprotective products. Furthermore, some phytochemicals may only be effective via topical administration if they exert their effects by absorbing UVR, making them unsuitable for systemic photoprotection.

Because alternatives to conventional treatments are being considered, it is important to remember that photoprotection requires a degree of individualisation: side effects that are unacceptable to some individuals may be tolerable to others, if the treatment decreases the risk of carcinogenesis. Thus, phytochemicals with photoprotective properties could be administered in safe and effective doses to less affected individuals where milder strategies may still provide an effect. Whereas patients receiving immunosuppressive treatments who have a higher risk of developing KCs should be treated with more aggressive pharmaceutical therapies to ensure efficient treatment of the carcinomas.

Photoprevention in its current stage is focused on preventing the initial steps of KC development by counteracting the adverse effects induced by UVR exposure. However, increasing evidence has demonstrated that phytochemical supplementation to cancer treatments such as chemotherapy may improve treatment outcome. In chemotherapy, natural or synthetic compounds such as bleomycin, cisplatin and taxol induce cytotoxicity in tumour cells by interfering with DNA replication and mitosis to prevent tumour proliferation. The addition of certain phytochemicals to these treatments have demonstrated better outcomes, either by improving treatment efficacy, drug delivery and accumulation [246] or improving management of side effects in in vitro and pre-clinical models [247], which is further reviewed here [248].

In general, more studies are needed to clarify whether photoprotectants on their own can be used as anticarcinogenic therapies, as well as to identify the most promising targets for photoprotection. Because these compounds may display weak pharmacological potencies, efficient use may require modification either through synthetically edited structures or the use of adjuvants to improve results. As the compounds presented in this review affect several different targets, optimisation of their cellular effects must also be considered. Signal transduction is a delicate process evolved to respond to different stimuli resulting in unexpected results that can both promote and prevent cellular growth. As such, treatment with these compounds must be optimised through comprehensive studies to ensure that the induced outcome is predominantly anticarcinogenic.

In this review, we have discussed the photoprotective potential of 15 different categories across pharmaceuticals, phytochemicals and vitamins (Tables 2-4). We have also provided an overview of the current understanding of the UV-induced events they target under the headings of DNA damage, oxidative stress, inflammation, immunosuppression and dysregulated signal transduction, as summarised in Figure 3. 


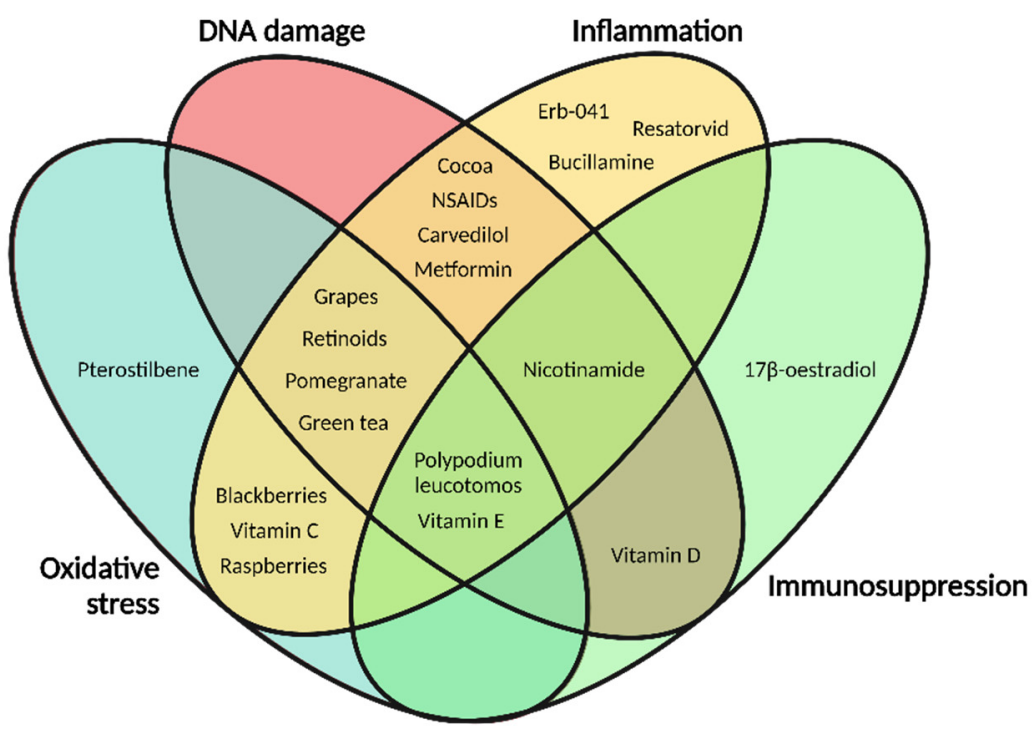

Figure 3. Overview of the reviewed compounds and their mechanisms. The Venn diagram represents four of the five UV-induced events (DNA damage, oxidative stress, inflammation and immunosuppression). UV-induced events targeted by each compound are shown. Dysregulated signal transduction is not included in the figure as it can be reflected as induction and stimulation of the other four UV-induced events. Abbreviations: NSAIDs, non-steroidal anti-inflammatory drugs.

Numerous of studies have explored the extensive possibilities of photoprotectants, and through thorough investigations focusing on the various mechanisms of action following oral delivery, the challenge will now be to identify the most promising candidates to provide the best possible photoprotection to prevent skin cancer.

Author Contributions: Original draft preparation of the manuscript, C.P. Review and editing of the manuscript, C.M.L., C.P., F.A., K.T.-B., M.H. and P.B. Supervision, C.M.L. All authors have read and agreed to the published version of the manuscript.

Funding: C.M.L is supported by an unrestricted grant from the Lundbeck Foundation (R307-20183318). C.P. is supported by the Danish Research Center for Skin Cancer, a public-private research partnership between the Private Hospital Molholm, Aalborg University Hospital and Copenhagen University Hospital, Bispebjerg and Frederiksberg.

Acknowledgments: This work was executed as a part of the Danish Research Center for Skin Cancer and the Skin Cancer Innovation Clinical Academic Group (SCIN CAG), Greater Copenhagen Health Science Partners (GCHSP). Figures were created with BioRender.com on 28 June 2021.

Conflicts of Interest: The authors declare no conflict of interest.

\section{References}

1. Lomas, A.; Leonardi-Bee, J.; Bath-Hextall, F. A Systematic Review of Worldwide Incidence of Nonmelanoma Skin Cancer. Br. J. Dermatol. 2012, 166, 1069-1080. [CrossRef] [PubMed]

2. Kim, Y.; He, Y.-Y. Ultraviolet Radiation-Induced Non-Melanoma Skin Cancer: Regulation of DNA Damage Repair and Inflammation. Genes Dis. 2014, 1, 188-198. [CrossRef]

3. Dale Wilson, B.; Moon, S.; Armstrong, F. Comprehensive Review of Ultraviolet Radiation and the Current Status on Sunscreens. J. Clin. Aesthet. Dermatol. 2012, 5, 18-23.

4. Jans, J.; Schul, W.; Sert, Y.-G.; Rijksen, Y.; Rebel, H.; Eker, A.P.M.; Nakajima, S.; van Steeg, H.; de Gruijl, F.R.; Yasui, A.; et al. Powerful Skin Cancer Protection by a CPD-Photolyase Transgene. Curr. Biol. CB 2005, 15, 105-115. [CrossRef]

5. Brash, D.E. Sunlight and the Onset of Skin Cancer. Trends Genet. TIG 1997, 13, 410-414. [CrossRef]

6. Chatterjee, N.; Walker, G.C. Mechanisms of DNA Damage, Repair, and Mutagenesis. Environ. Mol. Mutagen. 2017, 58, 235-263. [CrossRef] [PubMed]

7. De Feraudy, S.; Ridd, K.; Richards, L.M.; Kwok, P.-Y.; Revet, I.; Oh, D.; Feeney, L.; Cleaver, J.E. The DNA Damage-Binding Protein XPC Is a Frequent Target for Inactivation in Squamous Cell Carcinomas. Am. J. Pathol. 2010, 177, 555-562. [CrossRef] [PubMed] 
8. Brash, D.E.; Rudolph, J.A.; Simon, J.A.; Lin, A.; McKenna, G.J.; Baden, H.P.; Halperin, A.J.; Pontén, J. A Role for Sunlight in Skin Cancer: UV-Induced P53 Mutations in Squamous Cell Carcinoma. Proc. Natl. Acad. Sci. USA 1991, 88, 10124. [CrossRef] [PubMed]

9. Muller, P.A.J.; Vousden, K.H. Mutant P53 in Cancer: New Functions and Therapeutic Opportunities. Cancer Cell 2014, 25, 304-317. [CrossRef]

10. Deliconstantinos, G.; Villiotou, V.; Stavrides, J.C. Alterations of Nitric Oxide Synthase and Xanthine Oxidase Activities of Human Keratinocytes by Ultraviolet B Radiation. Potential Role for Peroxynitrite in Skin Inflammation. Biochem. Pharmacol. 1996, 51, 1727-1738. [CrossRef]

11. Brem, R.; Macpherson, P.; Guven, M.; Karran, P. Oxidative Stress Induced by UVA Photoactivation of the Tryptophan UVB Photoproduct 6-Formylindolo[3,2-b]Carbazole (FICZ) Inhibits Nucleotide Excision Repair in Human Cells. Sci. Rep. 2017, 7, 4310. [CrossRef]

12. Podda, M.; Traber, M.G.; Weber, C.; Yan, L.-J.; Packer, L. UV-Irradiation Depletes Antioxidants and Causes Oxidative Damage in a Model of Human Skin. Free Radic. Biol. Med. 1998, 24, 55-65. [CrossRef]

13. Kawanishi, S.; Hiraku, Y.; Oikawa, S. Mechanism of Guanine-Specific DNA Damage by Oxidative Stress and Its Role in Carcinogenesis and Aging. Mutat. Res. Mutat. Res. 2001, 488, 65-76. [CrossRef]

14. Hattorinakakuki, Y.; Nishigori, C.; Okamoto, K.; Imamura, S.; Hiai, H.; Toyokuni, S. Formation of 8-Hydroxy-2'-Deoxyguanosine in Epidermis of Hairless Mice Exposed to Near-UV. Biochem. Biophys. Res. Commun. 1994, 201, 1132-1139. [CrossRef] [PubMed]

15. Shibutani, S.; Takeshita, M.; Grollman, A.P. Insertion of Specific Bases during DNA Synthesis Past the Oxidation-Damaged Base 8-OxodG. Nature 1991, 349, 431-434. [CrossRef] [PubMed]

16. Yin, H.; Xu, L.; Porter, N.A. Free Radical Lipid Peroxidation: Mechanisms and Analysis. Chem. Rev. 2011, 111, 5944-5972. [CrossRef] [PubMed]

17. Szarka, A.; Tomasskovics, B.; Bánhegyi, G. The Ascorbate-Glutathione- $\alpha$-Tocopherol Triad in Abiotic Stress Response. Int. J. Mol. Sci. 2012, 13, 4458-4483. [CrossRef]

18. Ramana, K.V.; Srivastava, S.; Singhal, S.S. Lipid Peroxidation Products in Human Health and Disease 2014. Oxid. Med. Cell. Longev. 2014, 2014, 162414. [CrossRef] [PubMed]

19. Schaur, R.J. Basic Aspects of the Biochemical Reactivity of 4-Hydroxynonenal. Mol. Asp. Med. 2003, 24, 149-159. [CrossRef]

20. Davies, M.J. Singlet Oxygen-Mediated Damage to Proteins and Its Consequences. Biochem. Biophys. Res. Commun. 2003, 305, 761-770. [CrossRef]

21. Dalle-Donne, I.; Giustarini, D.; Colombo, R.; Rossi, R.; Milzani, A. Protein Carbonylation in Human Diseases. Trends Mol. Med. 2003, 9, 169-176. [CrossRef]

22. Petrov, D.; Zagrovic, B. Microscopic Analysis of Protein Oxidative Damage: Effect of Carbonylation on Structure, Dynamics, and Aggregability of Villin Headpiece. J. Am. Chem. Soc. 2011, 133, 7016-7024. [CrossRef]

23. Zimmerman, R.; Cerutti, P. Active Oxygen Acts as a Promoter of Transformation in Mouse Embryo C3H/10T1/2/C18 Fibroblasts. Proc. Natl. Acad. Sci. USA 1984, 81, 2085. [CrossRef]

24. Zawrotniak, M.; Bartnicka, D.; Rapala-Kozik, M. UVA and UVB Radiation Induce the Formation of Neutrophil Extracellular Traps by Human Polymorphonuclear Cells. J. Photochem. Photobiol. B 2019, 196, 111511. [CrossRef]

25. Kato, T.; Delhase, M.; Hoffmann, A.; Karin, M. CK2 Is a C-Terminal IкB Kinase Responsible for NF-KB Activation during the UV Response. Mol. Cell 2003, 12, 829-839. [CrossRef]

26. May, M.J.; Ghosh, S. Rel/NF-KB and IkB Proteins: An Overview. Semin. Cancer Biol. 1997, 8, 63-73. [CrossRef]

27. Abeyama, K.; Eng, W.; Jester, J.V.; Vink, A.A.; Edelbaum, D.; Cockerell, C.J.; Bergstresser, P.R.; Takashima, A. A Role for NF-KB-Dependent Gene Transactivation in Sunburn. J. Clin. Investig. 2000, 105, 1751-1759. [CrossRef] [PubMed]

28. Bachelor, M.A.; Cooper, S.J.; Sikorski, E.T.; Bowden, G.T. Inhibition of P38 Mitogen-Activated Protein Kinase and Phosphatidylinositol 3-Kinase Decreases UVB-Induced Activator Protein-1 and Cyclooxygenase-2 in a SKH-1 Hairless Mouse Model. Mol. Cancer Res. MCR 2005, 3, 90-99. [CrossRef] [PubMed]

29. Kabashima, K.; Nagamachi, M.; Honda, T.; Nishigori, C.; Miyachi, Y.; Tokura, Y.; Narumiya, S. Prostaglandin E2 Is Required for Ultraviolet B-Induced Skin Inflammation via EP2 and EP4 Receptors. Lab. Investig. 2007, 87, 49-55. [CrossRef]

30. Narumiya, S.; Sugimoto, Y.; Ushikubi, F. Prostanoid Receptors: Structures, Properties, and Functions. Physiol. Rev. 1999, 79, 1193-1226. [CrossRef] [PubMed]

31. Stingl, L.A.; Sauder, D.N.; Iijima, M.; Wolff, K.; Pehamberger, H.; Stingl, G. Mechanism of UV-B-Induced Impairment of the Antigen-Presenting Capacity of Murine Epidermal Cells. J. Immunol. Baltim. 1983, 130, 1586-1591.

32. Aberer, W.; Schuler, G.; Stingl, G.; Hönigsmann, H.; Wolff, K. Ultraviolet Light Depletes Surface Markers of Langerhans Cells. J. Investig. Dermatol. 1981, 76, 202-210. [CrossRef]

33. Fukunaga, A.; Khaskhely, N.M.; Ma, Y.; Sreevidya, C.S.; Taguchi, K.; Nishigori, C.; Ullrich, S.E. Langerhans Cells Serve as Immunoregulatory Cells by Activating NKT Cells. J. Immunol. 2010, 185, 4633. [CrossRef] [PubMed]

34. Norval, M.; Simpson, T.J.; Ross, J.A. Urocanic Acid and Immunosuppression. Photochem. Photobiol. 1989, 50, 267-275. [CrossRef] [PubMed]

35. Noonan, F.P.; De Fabo, E.C. Immunosuppression by Ultraviolet B Radiation: Initiation by Urocanic Acid. Immunol. Today 1992, 13, 250-254. [CrossRef] 
36. Kaneko, K.; Smetana-Just, U.; Matsui, M.; Young, A.R.; John, S.; Norval, M.; Walker, S.L. Cis-Urocanic Acid Initiates Gene Transcription in Primary Human Keratinocytes. J. Immunol. 2008, 181, 217. [CrossRef]

37. Shreedhar, V.; Giese, T.; Sung, V.W.; Ullrich, S.E. A Cytokine Cascade Including Prostaglandin E2, IL-4, and IL-10 Is Responsible for UV-Induced Systemic Immune Suppression. J. Immunol. 1998, 160, 3783.

38. Rivas, J.M.; Ullrich, S.E. Systemic Suppression of Delayed-Type Hypersensitivity by Supernatants from UV-Irradiated Keratinocytes. An Essential Role for Keratinocyte-Derived IL-10. J. Immunol. 1992, 149, 3865-3871.

39. Mittal, S.K.; Cho, K.-J.; Ishido, S.; Roche, P.A. Interleukin 10 (IL-10)-Mediated Immunosuppression: March-I Induction Regulates Antigen Presentation by Macrophages but Not Dendritic Cells. J. Biol. Chem. 2015, 290, 27158-27167. [CrossRef]

40. Noske, K. Secreted Immunoregulatory Proteins in the Skin. J. Dermatol. Sci. 2018, 89, 3-10. [CrossRef]

41. Wu, C.L.; Qiang, L.; Han, W.; Ming, M.; Viollet, B.; He, Y.Y. Role of AMPK in UVB-Induced DNA Damage Repair and Growth Control. Oncogene 2013, 32, 2682-2689. [CrossRef]

42. Bode, A.M.; Dong, Z. Mitogen-Activated Protein Kinase Activation in UV-Induced Signal Transduction. Sci. STKE Signal Transduct. Knowl. Environ. 2003, 2003, RE2. [CrossRef]

43. De Gruijl, F.R.; Forbes, P.D. UV-induced Skin Cancer in a Hairless Mouse Model. BioEssays 1995, 17, 651-660. [CrossRef]

44. Zarghi, A.; Arfaei, S. Selective COX-2 Inhibitors: A Review of Their Structure-Activity Relationships. Iran. J. Pharm. Res. IJPR 2011, 10, 655-683. [PubMed]

45. Tang, X.; Kim, A.L.; Kopelovich, L.; Bickers, D.R.; Athar, M. Cyclooxygenase-2 Inhibitor Nimesulide Blocks Ultraviolet B-Induced Photocarcinogenesis in SKH-1 Hairless Mice. Photochem. Photobiol. 2008, 84, 522-527. [CrossRef] [PubMed]

46. Reeve, V.E.; Matheson, M.J.; Bosnic, M.; Boehm-Wilcox, C. The Protective Effect of Indomethacin on Photocarcinogenesis in Hairless Mice. Cancer Lett. 1995, 95, 213-219. [CrossRef]

47. Rahman, H.; Kumar, D.; Liu, T.; Okwundu, N.; Lum, D.; Florell, S.R.; Burd, C.E.; Boucher, K.M.; VanBrocklin, M.W.; Grossman, D. Aspirin Protects Melanocytes and Keratinocytes against UVB-Induced DNA Damage In Vivo. J. Investig. Dermatol. 2021, 141, 132-141.e3. [CrossRef] [PubMed]

48. Pentland, A.P.; Schoggins, J.W.; Scott, G.A.; Khan, K.N.; Han, R. Reduction of UV-Induced Skin Tumors in Hairless Mice by Selective COX-2 Inhibition. Carcinogenesis 1999, 20, 1939-1944. [CrossRef]

49. Athar, M.; An, K.P.; Tang, X.; Morel, K.D.; Kim, A.L.; Kopelovich, L.; Bickers, D.R. Photoprotective Effects of Sulindac against Ultraviolet B-Induced Phototoxicity in the Skin of SKH-1 Hairless Mice. Toxicol. Appl. Pharmacol. 2004, 195, 370-378. [CrossRef]

50. Elmets, C.A.; Viner, J.L.; Pentland, A.P.; Cantrell, W.; Lin, H.-Y.; Bailey, H.; Kang, S.; Linden, K.G.; Heffernan, M.; Duvic, M.; et al. Chemoprevention of Nonmelanoma Skin Cancer with Celecoxib: A Randomized, Double-Blind, Placebo-Controlled Trial. JNCI J. Natl. Cancer Inst. 2010, 102, 1835-1844. [CrossRef] [PubMed]

51. Campione, E.; Diluvio, L.; Paternò, E.J.; Chimenti, S. Topical Treatment of Actinic Keratoses with Piroxicam 1\% Gel: A Preliminary Open-Label Study Utilizing a New Clinical Score. Am. J. Clin. Dermatol. 2010, 11, 45-50. [CrossRef]

52. Trelle, S.; Reichenbach, S.; Wandel, S.; Hildebrand, P.; Tschannen, B.; Villiger, P.M.; Egger, M.; Jüni, P. Cardiovascular Safety of Non-Steroidal Anti-Inflammatory Drugs: Network Meta-Analysis. BMJ 2011, 342, c7086. [CrossRef] [PubMed]

53. Straube, S.; Tramèr, M.R.; Moore, R.A.; Derry, S.; McQuay, H.J. Mortality with Upper Gastrointestinal Bleeding and Perforation: Effects of Time and NSAID Use. BMC Gastroenterol. 2009, 9, 41. [CrossRef] [PubMed]

54. Huerta, C.; Castellsague, J.; Varas-Lorenzo, C.; García Rodríguez, L.A. Nonsteroidal Anti-Inflammatory Drugs and Risk of ARF in the General Population. Am. J. Kidney Dis. Off. J. Natl. Kidney Found. 2005, 45, 531-539. [CrossRef] [PubMed]

55. Luo, Z.; Zang, M.; Guo, W. AMPK as a Metabolic Tumor Suppressor: Control of Metabolism and Cell Growth. Future Oncol. Lond. Engl. 2010, 6, 457-470. [CrossRef]

56. Jones, R.G.; Plas, D.R.; Kubek, S.; Buzzai, M.; Mu, J.; Xu, Y.; Birnbaum, M.J.; Thompson, C.B. AMP-Activated Protein Kinase Induces a P53-Dependent Metabolic Checkpoint. Mol. Cell 2005, 18, 283-293. [CrossRef] [PubMed]

57. He, G.; Zhang, Y.-W.; Lee, J.-H.; Zeng, S.X.; Wang, Y.V.; Luo, Z.; Dong, X.C.; Viollet, B.; Wahl, G.M.; Lu, H. AMP-Activated Protein Kinase Induces P53 by Phosphorylating MDMX and Inhibiting Its Activity. Mol. Cell. Biol. 2014, 34, 148-157. [CrossRef]

58. Kirpichnikov, D.; McFarlane, S.I.; Sowers, J.R. Metformin: An Update. Ann. Intern. Med. 2002, 137, 25-33. [CrossRef] [PubMed]

59. DeCensi, A.; Puntoni, M.; Goodwin, P.; Cazzaniga, M.; Gennari, A.; Bonanni, B.; Gandini, S. Metformin and Cancer Risk in Diabetic Patients: A Systematic Review and Meta-Analysis. Cancer Prev. Res. 2010, 3, 1451. [CrossRef]

60. Ba, W.; Xu, Y.; Yin, G.; Yang, J.; Wang, R.; Chi, S.; Wang, Y.; Li, C. Metformin Inhibits Pro-Inflammatory Responses via Targeting Nuclear Factor-KB in HaCaT Cells. Cell Biochem. Funct. 2019, 37, 4-10. [CrossRef]

61. Chaudhary, S.C.; Kurundkar, D.; Elmets, C.A.; Kopelovich, L.; Athar, M. Metformin, an Antidiabetic Agent Reduces Growth of Cutaneous Squamous Cell Carcinoma by Targeting MTOR Signaling Pathway. Photochem. Photobiol. 2012, 88, 1149-1156. [CrossRef]

62. Cui, B.; Liu, Q.; Tong, L.; Feng, X. The Effects of the Metformin on Inhibition of UVA-Induced Expression of MMPs and COL-I in Human Skin Fibroblasts. Eur. J. Inflamm. 2019, 17, 2058739219876423. [CrossRef]

63. Bonnans, C.; Chou, J.; Werb, Z. Remodelling the Extracellular Matrix in Development and Disease. Nat. Rev. Mol. Cell Biol. 2014, 15, 786-801. [CrossRef] [PubMed]

64. Reddi, A.; Powers, M.A.; Dellavalle, R.P. Therapeutic Potential of the Anti-Diabetic Agent Metformin in Targeting the Skin Cancer Stem Cell Diaspora. Exp. Dermatol. 2014, 23, 345-346. [CrossRef] [PubMed] 
65. Pienta, K.J.; Robertson, B.A.; Coffey, D.S.; Taichman, R.S. The Cancer Diaspora: Metastasis beyond the Seed and Soil Hypothesis. Clin. Cancer Res. Off. J. Am. Assoc. Cancer Res. 2013, 19, 5849-5855. [CrossRef] [PubMed]

66. Tseng, C.-H. Metformin Is Associated with Decreased Skin Cancer Risk in Taiwanese Patients with Type 2 Diabetes. J. Am. Acad. Dermatol. 2018, 78, 694-700. [CrossRef] [PubMed]

67. Adalsteinsson, J.A.; Muzumdar, S.; Waldman, R.; Wu, R.; Ratner, D.; Feng, H.; Ungar, J.; Silverberg, J.I.; Olafsdottir, G.H.; Kristjansson, A.K.; et al. Metformin Is Associated with Decreased Risk of Basal Cell Carcinoma: A Whole-Population CaseControl Study from Iceland. J. Am. Acad. Dermatol. 2021, 85, 56-61. [CrossRef]

68. Zhou, Q.; Kim, S.H.; Pérez-Lorenzo, R.; Liu, C.; Huang, M.; Dotto, G.P.; Zheng, B.; Wu, X. Phenformin Promotes Keratinocyte Differentiation via the Calcineurin/NFAT Pathway. J. Investig. Dermatol. 2021, 141, 152-163. [CrossRef]

69. Jung, J.; Bollag, W.B. Phenformin: AMP(K)Ed for Potential Repurposing. J. Investig. Dermatol. 2021, 141, 11-14. [CrossRef]

70. Chen, L.; Guo, S.; Ranzer, M.J.; DiPietro, L.A. Toll-like Receptor 4 Has an Essential Role in Early Skin Wound Healing. J. Investig. Dermatol. 2013, 133, 258-267. [CrossRef]

71. Min, W.; Ahmad, I.; Chang, M.E.; Burns, E.M.; Qian, Q.; Yusuf, N. Baicalin Protects Keratinocytes from Toll-like Receptor-4 Mediated DNA Damage and Inflammation Following Ultraviolet Irradiation. Photochem. Photobiol. 2015, 91, 1435-1443. [CrossRef]

72. Janda, J.; Burkett, N.B.; Blohm-Mangone, K.; Huang, V.; Curiel-Lewandrowski, C.; Alberts, D.S.; Petricoin, E.F., 3rd; Calvert, V.S.; Einspahr, J.; Dong, Z.; et al. Resatorvid-Based Pharmacological Antagonism of Cutaneous TLR4 Blocks UV-Induced NF-KB and AP-1 Signaling in Keratinocytes and Mouse Skin. Photochem. Photobiol. 2016, 92, 816-825. [CrossRef] [PubMed]

73. Matsunaga, N.; Tsuchimori, N.; Matsumoto, T.; Ii, M. TAK-242 (Resatorvid), a Small-Molecule Inhibitor of Toll-like Receptor (TLR) 4 Signaling, Binds Selectively to TLR4 and Interferes with Interactions between TLR4 and Its Adaptor Molecules. Mol. Pharmacol. 2011, 79, 34-41. [CrossRef] [PubMed]

74. Feng, Y.; Gao, J.; Cui, Y.; Li, M.; Li, R.; Cui, C.; Cui, J. Neuroprotective Effects of Resatorvid Against Traumatic Brain Injury in Rat: Involvement of Neuronal Autophagy and TLR4 Signaling Pathway. Cell. Mol. Neurobiol. 2017, 37, 155-168. [CrossRef] [PubMed]

75. Zandi, Z.; Kashani, B.; Poursani, E.M.; Bashash, D.; Kabuli, M.; Momeny, M.; Mousavi-Pak, S.H.; Sheikhsaran, F.; Alimoghaddam, K.; Mousavi, S.A.; et al. TLR4 Blockade Using TAK-242 Suppresses Ovarian and Breast Cancer Cells Invasion through the Inhibition of Extracellular Matrix Degradation and Epithelial-Mesenchymal Transition. Eur. J. Pharmacol. 2019, 853, $256-263$. [CrossRef] [PubMed]

76. Blohm-Mangone, K.; Burkett, N.B.; Tahsin, S.; Myrdal, P.B.; Aodah, A.; Ho, B.; Janda, J.; McComas, M.; Saboda, K.; Roe, D.J.; et al. Pharmacological TLR4 Antagonism Using Topical Resatorvid Blocks Solar UV-Induced Skin Tumorigenesis in SKH-1 Mice. Cancer Prev. Res. 2018, 11, 265-278. [CrossRef] [PubMed]

77. Rice, T.W.; Wheeler, A.P.; Bernard, G.R.; Vincent, J.-L.; Angus, D.C.; Aikawa, N.; Demeyer, I.; Sainati, S.; Amlot, N.; Cao, C.; et al. A Randomized, Double-Blind, Placebo-Controlled Trial of TAK-242 for the Treatment of Severe Sepsis. Crit. Care Med. 2010, 38, 1685-1694. [CrossRef] [PubMed]

78. Zhou, Y.; Liu, X. The Role of Estrogen Receptor Beta in Breast Cancer. Biomark. Res. 2020, 8, 39. [CrossRef]

79. Chang, E.C.; Frasor, J.; Komm, B.; Katzenellenbogen, B.S. Impact of Estrogen Receptor $\beta$ on Gene Networks Regulated by Estrogen Receptor $\alpha$ in Breast Cancer Cells. Endocrinology 2006, 147, 4831-4842. [CrossRef]

80. Malamas, M.S.; Manas, E.S.; McDevitt, R.E.; Gunawan, I.; Xu, Z.B.; Collini, M.D.; Miller, C.P.; Dinh, T.; Henderson, R.A.; Keith, J.C.; et al. Design and Synthesis of Aryl Diphenolic Azoles as Potent and Selective Estrogen Receptor- $\beta$ Ligands. J. Med. Chem. 2004, 47, 5021-5040. [CrossRef]

81. Roman-Blas, J.A.; Castañeda, S.; Cutolo, M.; Herrero-Beaumont, G. Efficacy and Safety of a Selective Estrogen Receptor $\beta$ Agonist, ERB-041, in Patients with Rheumatoid Arthritis: A 12-Week, Randomized, Placebo-Controlled, Phase II Study. Arthritis Care Res. 2010, 62, 1588-1593. [CrossRef] [PubMed]

82. Chaudhary, S.C.; Singh, T.; Talwelkar, S.S.; Srivastava, R.K.; Arumugam, A.; Weng, Z.; Elmets, C.A.; Afaq, F.; Kopelovich, L.; Athar, M. Erb-041, an Estrogen Receptor- $\beta$ Agonist, Inhibits Skin Photocarcinogenesis in SKH-1 Hairless Mice by Downregulating the WNT Signaling Pathway. Cancer Prev. Res. 2014, 7, 186-198. [CrossRef]

83. Hiramoto, K.; Tanaka, H.; Yanagihara, N.; Sato, E.F.; Inoue, M. Effect of $17 \beta$-Estradiol on Immunosuppression Induced by Ultraviolet B Irradiation. Arch. Dermatol. Res. 2004, 295, 307-311. [CrossRef] [PubMed]

84. Vitale, D.C.; Piazza, C.; Melilli, B.; Drago, F.; Salomone, S. Isoflavones: Estrogenic Activity, Biological Effect and Bioavailability. Eur. J. Drug Metab. Pharmacokinet. 2013, 38, 15-25. [CrossRef]

85. Torrens-Mas, M.; Roca, P. Phytoestrogens for Cancer Prevention and Treatment. Biology 2020, 9, 427. [CrossRef] [PubMed]

86. Hara, M.R.; Kovacs, J.J.; Whalen, E.J.; Rajagopal, S.; Strachan, R.T.; Grant, W.; Towers, A.J.; Williams, B.; Lam, C.M.; Xiao, K.; et al. A Stress Response Pathway Regulates DNA Damage through B2-Adrenoreceptors and $\beta$-Arrestin-1. Nature 2011, 477, 349-353. [CrossRef]

87. Seiffert, K.; Hosoi, J.; Torii, H.; Ozawa, H.; Ding, W.; Campton, K.; Wagner, J.A.; Granstein, R.D. Catecholamines Inhibit the Antigen-Presenting Capability of Epidermal Langerhans Cells. J. Immunol. 2002, 168, 6128. [CrossRef]

88. Steinkraus, V.; Steinfath, M.; Körner, C.; Mensing, H. Binding of Beta-Adrenergic Receptors in Human Skin. J. Investig. Dermatol. 1992, 98, 475-480. [CrossRef]

89. Chen, M.; Liang, S.; Shahid, A.; Andresen, B.T.; Huang, Y. The $\beta$-Blocker Carvedilol Prevented Ultraviolet-Mediated Damage of Murine Epidermal Cells and 3D Human Reconstructed Skin. Int. J. Mol. Sci. 2020, 21, 798. [CrossRef] [PubMed] 
90. Huang, K.M.; Liang, S.; Yeung, S.; Oiyemhonlan, E.; Cleveland, K.H.; Parsa, C.; Orlando, R.; Meyskens, F.L.; Andresen, B.T.; Huang, Y. Topically Applied Carvedilol Attenuates Solar Ultraviolet Radiation Induced Skin Carcinogenesis. Cancer Prev. Res. 2017, 10, 598. [CrossRef]

91. Chen, M.; Shamim, M.A.; Shahid, A.; Yeung, S.; Andresen, B.T.; Wang, J.; Nekkanti, V.; Meyskens, F.L.J.; Kelly, K.M.; Huang, Y. Topical Delivery of Carvedilol Loaded Nano-Transfersomes for Skin Cancer Chemoprevention. Pharmaceutics 2020, 12, 1151. [CrossRef] [PubMed]

92. Suda, A.; Nagaoka, S.; Ohono, S.; Ideguchi, H.; Soga, T.; Ishigatsubo, Y. The Efficacy and Safety of Bucillamine as a Second-Line DMARD in the Treatment of Rheumatoid Arthritis: A Retrospective Cohort Study. Mod. Rheumatol. 2008, 18, 609-614. [CrossRef] [PubMed]

93. D'Agostini, F.; Balansky, R.M.; Camoirano, A.; De Flora, S. Modulation of Light-Induced Skin Tumors by N-Acetylcysteine and/or Ascorbic Acid in Hairless Mice. Carcinogenesis 2005, 26, 657-664. [CrossRef] [PubMed]

94. Mazor, D.; Greenberg, L.; Shamir, D.; Meyerstein, D.; Meyerstein, N. Antioxidant Properties of Bucillamine: Possible Mode of Action. Biochem. Biophys. Res. Commun. 2006, 349, 1171-1175. [CrossRef] [PubMed]

95. Anwar, A.; Anwar, H.; Yamauchi, T.; Tseng, R.; Agarwal, R.; Horwitz, L.D.; Zhai, Z.; Fujita, M. Bucillamine Inhibits UVB-Induced MAPK Activation and Apoptosis in Human HaCaT Keratinocytes and SKH-1 Hairless Mouse Skin. Photochem. Photobiol. 2020, 96, 870-876. [CrossRef] [PubMed]

96. Anwar, A.; Gu, M.; Brady, S.; Qamar, L.; Behbakht, K.; Shellman, Y.G.; Agarwal, R.; Norris, D.A.; Horwitz, L.D.; Fujita, M. Photoprotective Effects of Bucillamine Against UV-Induced Damage in an SKH-1 Hairless Mouse Model. Photochem. Photobiol. 2008, 84, 477-483. [CrossRef] [PubMed]

97. Choudhari, A.S.; Mandave, P.C.; Deshpande, M.; Ranjekar, P.; Prakash, O. Phytochemicals in Cancer Treatment: From Preclinical Studies to Clinical Practice. Front. Pharmacol. 2020, 10, 1614. [CrossRef]

98. Paiva, L.; Rego, C.; Lima, E.; Marcone, M.; Baptista, J. Comparative Analysis of the Polyphenols, Caffeine, and Antioxidant Activities of Green Tea, White Tea, and Flowers from Azorean Camellia Sinensis Varieties Affected by Different Harvested and Processing Conditions. Antioxidants 2021, 10, 183. [CrossRef]

99. Abotorabi, Z.; Khorashadizadeh, M.; Arab, M.; Hassanpour Fard, M.; Zarban, A. Jujube and Green Tea Extracts Protect Human Fibroblast Cells against UVB-Mediated Photo Damage and MMP-2 and MMP-9 Production. Avicenna J. Phytomed. 2020, 10, 287-296.

100. Katiyar, S.K.; Afaq, F.; Azizuddin, K.; Mukhtar, H. Inhibition of UVB-Induced Oxidative Stress-Mediated Phosphorylation of Mitogen-Activated Protein Kinase Signaling Pathways in Cultured Human Epidermal Keratinocytes by Green Tea Polyphenol (-)-Epigallocatechin-3-Gallate. Toxicol. Appl. Pharmacol. 2001, 176, 110-117. [CrossRef]

101. Song, X.; Bi, Z.; Xu, A. Green Tea Polyphenol Epigallocatechin-3-Gallate Inhibits the Expression of Nitric Oxide Synthase and Generation of Nitric Oxide Induced by Ultraviolet B in HaCaT Cells. Chin. Med. J. (Engl.) 2006, 119, 282-287. [CrossRef]

102. Mittal, A.; Piyathilake, C.; Hara, Y.; Katiyar, S.K. Exceptionally High Protection of Photocarcinogenesis by Topical Application of (-)-Epigallocatechin-3-Gallate in Hydrophilic Cream in SKH-1 Hairless Mouse Model: Relationship to Inhibition of UVB-Induced Global DNA Hypomethylation. Neoplasia 2003, 5, 555-565. [CrossRef]

103. Meeran, S.M.; Akhtar, S.; Katiyar, S.K. Inhibition of UVB-Induced Skin Tumor Development by Drinking Green Tea Polyphenols Is Mediated through DNA Repair and Subsequent Inhibition of Inflammation. J. Investig. Dermatol. 2009, 129, 1258-1270. [CrossRef]

104. Wajed, S.A.; Laird, P.W.; DeMeester, T.R. DNA Methylation: An Alternative Pathway to Cancer. Ann. Surg. 2001, 234, 10-20. [CrossRef] [PubMed]

105. Schwarz, A.; Ständer, S.; Berneburg, M.; Böhm, M.; Kulms, D.; van Steeg, H.; Grosse-Heitmeyer, K.; Krutmann, J.; Schwarz, T. Interleukin-12 Suppresses Ultraviolet Radiation-Induced Apoptosis by Inducing DNA Repair. Nat. Cell Biol. 2002, 4, 26-31. [CrossRef] [PubMed]

106. Schwarz, A.; Maeda, A.; Gan, D.; Mammone, T.; Matsui, M.S.; Schwarz, T. Green Tea Phenol Extracts Reduce UVB-Induced DNA Damage in Human Cells via Interleukin-12. Photochem. Photobiol. 2008, 84, 350-355. [CrossRef] [PubMed]

107. Katiyar, S.K.; Perez, A.; Mukhtar, H. Green Tea Polyphenol Treatment to Human Skin Prevents Formation of Ultraviolet Light B-Induced Pyrimidine Dimers in DNA. Clin. CANCER Res. 2000, 6, 3864-3869. [PubMed]

108. Farrar, M.D.; Huq, R.; Mason, S.; Nicolaou, A.; Clarke, K.A.; Dew, T.P.; Williamson, G.; Watson, R.E.B.; Rhodes, L.E. Oral Green Tea Catechins Do Not Provide Photoprotection from Direct DNA Damage Induced by Higher Dose Solar Simulated Radiation: A Randomized Controlled Trial. J. Am. Acad. Dermatol. 2018, 78, 414-416. [CrossRef]

109. Chow, H.-H.S.; Cai, Y.; Hakim, I.A.; Crowell, J.A.; Shahi, F.; Brooks, C.A.; Dorr, R.T.; Hara, Y.; Alberts, D.S. Pharmacokinetics and Safety of Green Tea Polyphenols after Multiple-Dose Administration of Epigallocatechin Gallate and Polyphenon E in Healthy Individuals. Clin. Cancer Res. 2003, 9, 3312.

110. Farrar, M.D.; Nicolaou, A.; Clarke, K.A.; Mason, S.; Massey, K.A.; Dew, T.P.; Watson, R.E.; Williamson, G.; Rhodes, L.E. A Randomized Controlled Trial of Green Tea Catechins in Protection against Ultraviolet Radiation-Induced Cutaneous Inflammation1,2. Am. J. Clin. Nutr. 2015, 102, 608-615. [CrossRef]

111. Friedman, M.; Levin, C.E.; Lee, S.-U.; Kozukue, N. Stability of Green Tea Catechins in Commercial Tea Leaves during Storage for 6 Months. J. Food Sci. 2009, 74, H47-H51. [CrossRef]

112. Yang, C.S.; Chen, L.; Lee, M.J.; Balentine, D.; Kuo, M.C.; Schantz, S.P. Blood and Urine Levels of Tea Catechins after Ingestion of Different Amounts of Green Tea by Human Volunteers. Cancer Epidemiol. Biomark. 1998, 7, 351. 
113. Perde-Schrepler, M.; Chereches, G.; Brie, I.; Tatomir, C.; Postescu, I.D.; Soran, L.; Filip, A. Grape Seed Extract as Photochemopreventive Agent against UVB-Induced Skin Cancer. J. Photochem. Photobiol. B 2013, 118, 16-21. [CrossRef] [PubMed]

114. Sharma, S.D.; Katiyar, S.K. Dietary Grape Seed Proanthocyanidins Inhibit UVB-Induced Cyclooxygenase-2 Expression and Other Inflammatory Mediators in UVB-Exposed Skin and Skin Tumors of SKH-1 Hairless Mice. Pharm. Res. 2010, 27, $1092-1102$. [CrossRef] [PubMed]

115. Mintie, C.A.; Musarra, A.K.; Singh, C.K.; Ndiaye, M.A.; Sullivan, R.; Eickhoff, J.C.; Ahmad, N. Protective Effects of Dietary Grape on UVB-Mediated Cutaneous Damages and Skin Tumorigenesis in SKH-1 Mice. Cancers 2020, 12, 1751. [CrossRef]

116. Sharma, S.D.; Meeran, S.M.; Katiyar, S.K. Dietary Grape Seed Proanthocyanidins Inhibit UVB-Induced Oxidative Stress and Activation of Mitogen-Activated Protein Kinases and Nuclear Factor-KappaB Signaling in in Vivo SKH-1 Hairless Mice. Mol. Cancer Ther. 2007, 6, 995-1005. [CrossRef] [PubMed]

117. Sharma, S.D.; Katiyar, S.K. Dietary Grape-Seed Proanthocyanidin Inhibition of Ultraviolet B-Induced Immune Suppression Is Associated with Induction of IL-12. Carcinogenesis 2005, 27, 95-102. [CrossRef]

118. Vaid, M.; Sharma, S.D.; Katiyar, S.K. Proanthocyanidins Inhibit Photocarcinogenesis through Enhancement of DNA Repair and Xeroderma Pigmentosum Group A-Dependent Mechanism. Cancer Prev. Res. 2010, 3, 1621-1629. [CrossRef]

119. Oak, A.S.W.; Shafi, R.; Elsayed, M.; Bae, S.; Saag, L.; Wang, C.L.; Athar, M.; Elmets, C.A. Dietary Table Grape Protects against UV Photodamage in Humans: 1. Clinical Evaluation. J. Am. Acad. Dermatol. 2021. [CrossRef]

120. Oak, A.S.W.; Shafi, R.; Elsayed, M.; Mishra, B.; Bae, S.; Barnes, S.; Kashyap, M.P.; Slominski, A.T.; Wilson, L.S.; Athar, M.; et al Dietary Table Grape Protects against Ultraviolet Photodamage in Humans: 2. Molecular Biomarker Studies. J. Am. Acad. Dermatol. 2021. [CrossRef]

121. Kapetanovic, I.M.; Muzzio, M.; Huang, Z.; Thompson, T.N.; McCormick, D.L. Pharmacokinetics, Oral Bioavailability, and Metabolic Profile of Resveratrol and Its Dimethylether Analog, Pterostilbene, in Rats. Cancer Chemother. Pharmacol. 2011, 68, 593-601. [CrossRef] [PubMed]

122. Sirerol, J.A.; Feddi, F.; Mena, S.; Rodriguez, M.L.; Sirera, P.; Aupí, M.; Pérez, S.; Asensi, M.; Ortega, A.; Estrela, J.M. Topical Treatment with Pterostilbene, a Natural Phytoalexin, Effectively Protects Hairless Mice against UVB Radiation-Induced Skin Damage and Carcinogenesis. Free Radic. Biol. Med. 2015, 85, 1-11. [CrossRef]

123. Gombau, L.; García, F.; Lahoz, A.; Fabre, M.; Roda-Navarro, P.; Majano, P.; Alonso-Lebrero, J.L.; Pivel, J.P.; Castell, J.V.; GómezLechon, M.J.; et al. Polypodium Leucotomos Extract: Antioxidant Activity and Disposition. Toxicol. Vitr. 2006, 20, 464-471. [CrossRef]

124. Capote, R.; Alonso-Lebrero, J.L.; García, F.; Brieva, A.; Pivel, J.P.; González, S. Polypodium Leucotomos Extract Inhibits TransUrocanic Acid Photoisomerization and Photodecomposition. J. Photochem. Photobiol. B 2006, 82, 173-179. [CrossRef]

125. González, S.; Pathak, M.A. Inhibition of Ultraviolet-Induced Formation of Reactive Oxygen Species, Lipid Peroxidation, Erythema and Skin Photosensitization by Polypodium Leucotomos. Photodermatol. Photoimmunol. Photomed. 1996, 12, 45-56. [CrossRef]

126. Rodriguez-Yanes, E.; Juarranz, A.; Cuevas, J.; Gonzalez, S.; Mallol, J. Polypodium Leucotomos Decreases UV-Induced Epidermal Cell Proliferation and Enhances P53 Expression and Plasma Antioxidant Capacity in Hairless Mice. Exp. Dermatol. 2012, 21, 638-640. [CrossRef]

127. Zattra, E.; Coleman, C.; Arad, S.; Helms, E.; Levine, D.; Bord, E.; Guillaume, A.; El-Hajahmad, M.; Zwart, E.; van Steeg, H.; et al. Polypodium Leucotomos Extract Decreases UV-Induced Cox-2 Expression and Inflammation, Enhances DNA Repair, and Decreases Mutagenesis in Hairless Mice. Am. J. Pathol. 2009, 175, 1952-1961. [CrossRef]

128. Jańczyk, A.; Garcia-Lopez, M.A.; Fernandez-Peñas, P.; Alonso-Lebrero, J.L.; Benedicto, I.; López-Cabrera, M.; Gonzalez, S. A Polypodium Leucotomos Extract Inhibits Solar-Simulated Radiation-Induced TNF-Alpha and INOS Expression, Transcriptional Activation and Apoptosis. Exp. Dermatol. 2007, 16, 823-829. [CrossRef]

129. Siscovick, J.R.; Zapolanski, T.; Magro, C.; Carrington, K.; Prograis, S.; Nussbaum, M.; Gonzalez, S.; Ding, W.; Granstein, R.D. Polypodium Leucotomos Inhibits Ultraviolet B Radiation-Induced Immunosuppression. Photodermatol. Photoimmunol. Photomed. 2008, 24, 134-141. [CrossRef] [PubMed]

130. Mulero, M.; Rodríguez-Yanes, E.; Nogués, M.R.; Giralt, M.; Romeu, M.; González, S.; Mallol, J. Polypodium Leucotomos Extract Inhibits Glutathione Oxidation and Prevents Langerhans Cell Depletion Induced by UVB/UVA Radiation in a Hairless Rat Model. Exp. Dermatol. 2008, 17, 653-658. [CrossRef] [PubMed]

131. Rodríguez-Yanes, E.; Cuevas, J.; González, S.; Mallol, J. Oral Administration of Polypodium Leucotomos Delays Skin Tumor Development and Increases Epidermal P53 Expression and the Anti-Oxidant Status of UV-Irradiated Hairless Mice. Exp. Dermatol. 2014, 23, 526-528. [CrossRef]

132. Alcaraz, M.V.; Pathak, M.A.; Rius, F.; Kollias, N.; González, S. An Extract of Polypodium Leucotomos Appears to Minimize Certain Photoaging Changes in a Hairless Albino Mouse Animal Model: A Pilot Study. Photodermatol. Photoimmunol. Photomed. 1999, 15, 120-126. [CrossRef]

133. González, S.; Pathak, M.A.; Cuevas, J.; Villarrubia, V.G.; Fitzpatrick, T.B. Topical or Oral Administration with an Extract of Polypodium Leucotomos Prevents Acute Sunburn and Psoralen-Induced Phototoxic Reactions as Well as Depletion of Langerhans Cells in Human Skin. Photodermatol. Photoimmunol. Photomed. 1997, 13, 50-60. [CrossRef] [PubMed]

134. Middelkamp-Hup, M.A.; Pathak, M.A.; Parrado, C.; Garcia-Caballero, T.; Rius-Díaz, F.; Fitzpatrick, T.B.; González, S. Orally Administered Polypodium Leucotomos Extract Decreases Psoralen-UVA-Induced Phototoxicity, Pigmentation, and Damage of Human Skin. J. Am. Acad. Dermatol. 2004, 50, 41-49. [CrossRef] 
135. Middelkamp-Hup, M.A.; Pathak, M.A.; Parrado, C.; Goukassian, D.; Rius-Díaz, F.; Mihm, M.C.; Fitzpatrick, T.B.; González, S. Oral Polypodium Leucotomos Extract Decreases Ultraviolet-Induced Damage of Human Skin. J. Am. Acad. Dermatol. 2004, 51, 910-918. [CrossRef]

136. Kohli, I.; Shafi, R.; Isedeh, P.; Griffith, J.L.; Al-Jamal, M.S.; Silpa-Archa, N.; Jackson, B.; Athar, M.; Kollias, N.; Elmets, C.A.; et al. The Impact of Oral Polypodium Leucotomos Extract on Ultraviolet B Response: A Human Clinical Study. J. Am. Acad. Dermatol. 2017, 77, 33-41.e1. [CrossRef] [PubMed]

137. Nestor, M.S.; Berman, B.; Swenson, N. Safety and Efficacy of Oral Polypodium Leucotomos Extract in Healthy Adult Subjects. J. Clin. Aesthet. Dermatol. 2015, 8, 19-23. [PubMed]

138. Gil, M.I.; Tomás-Barberán, F.A.; Hess-Pierce, B.; Holcroft, D.M.; Kader, A.A. Antioxidant Activity of Pomegranate Juice and Its Relationship with Phenolic Composition and Processing. J. Agric. Food Chem. 2000, 48, 4581-4589. [CrossRef] [PubMed]

139. Khan, N.; Syed, D.N.; Pal, H.C.; Mukhtar, H.; Afaq, F. Pomegranate Fruit Extract Inhibits UVB-Induced Inflammation and Proliferation by Modulating NF-KB and MAPK Signaling Pathways in Mouse Skin. Photochem. Photobiol. 2012, 88, 1126-1134. [CrossRef] [PubMed]

140. Afaq, F.; Khan, N.; Syed, D.N.; Mukhtar, H. Oral Feeding of Pomegranate Fruit Extract Inhibits Early Biomarkers of UVB Radiation-Induced Carcinogenesis in SKH-1 Hairless Mouse Epidermis. Photochem. Photobiol. 2010, 86, 1318-1326. [CrossRef]

141. Gómez-García, F.J.; López López, A.; Guerrero-Sánchez, Y.; Sánchez Siles, M.; Martínez Díaz, F.; Camacho Alonso, F. Chemopreventive Effect of Pomegranate and Cocoa Extracts on Ultraviolet Radiation-Induced Photocarcinogenesis in SKH-1 Mice. PLoS ONE 2020, 15, e232009. [CrossRef]

142. Henning, S.M.; Yang, J.; Lee, R.-P.; Huang, J.; Hsu, M.; Thames, G.; Gilbuena, I.; Long, J.; Xu, Y.; Park, E.H.; et al. Pomegranate Juice and Extract Consumption Increases the Resistance to UVB-Induced Erythema and Changes the Skin Microbiome in Healthy Women: A Randomized Controlled Trial. Sci. Rep. 2019, 9, 14528. [CrossRef]

143. Duncan, F.J.; Martin, J.R.; Wulff, B.C.; Stoner, G.D.; Tober, K.L.; Oberyszyn, T.M.; Kusewitt, D.F.; Van Buskirk, A.M. Topical Treatment with Black Raspberry Extract Reduces Cutaneous UVB-Induced Carcinogenesis and Inflammation. Cancer Prev. Res. 2009, 2, 665-672. [CrossRef] [PubMed]

144. Wang, P.-W.; Cheng, Y.-C.; Hung, Y.-C.; Lee, C.-H.; Fang, J.-Y.; Li, W.-T.; Wu, Y.-R.; Pan, T.-L. Red Raspberry Extract Protects the Skin against UVB-Induced Damage with Antioxidative and Anti-Inflammatory Properties. Oxid. Med. Cell. Longev. 2019, 2019. [CrossRef] [PubMed]

145. Gao, W.; Wang, Y.; Hwang, E.; Lin, P.; Bae, J.; Seo, S.A.; Yan, Z.; Yi, T.-H. Rubus Idaeus L. (Red Raspberry) Blocks UVBInduced MMP Production and Promotes Type I Procollagen Synthesis via Inhibition of MAPK/AP-1, NF-K $\beta$ and Stimulation of TGF- $\beta$ /Smad, Nrf2 in Normal Human Dermal Fibroblasts. J. Photochem. Photobiol. B 2018, 185, 241-253. [CrossRef] [PubMed]

146. Divya, S.P.; Wang, X.; Pratheeshkumar, P.; Son, Y.-O.; Roy, R.V.; Kim, D.; Dai, J.; Hitron, J.A.; Wang, L.; Asha, P.; et al. Blackberry Extract Inhibits UVB-Induced Oxidative Damage and Inflammation through MAP Kinases and NF-KB Signaling Pathways in SKH-1 Mice Skin. Toxicol. Appl. Pharmacol. 2015, 284, 92-99. [CrossRef]

147. Pratheeshkumar, P.; Son, Y.-O.; Wang, X.; Divya, S.P.; Joseph, B.; Hitron, J.A.; Wang, L.; Kim, D.; Yin, Y.; Roy, R.V.; et al. Cyanidin3-Glucoside Inhibits UVB-Induced Oxidative Damage and Inflammation by Regulating MAP Kinase and NF-KB Signaling Pathways in SKH-1 Hairless Mice Skin. Toxicol. Appl. Pharmacol. 2014, 280, 127-137. [CrossRef] [PubMed]

148. Lee, K.W.; Kundu, J.K.; Kim, S.O.; Chun, K.-S.; Lee, H.J.; Surh, Y.-J. Cocoa Polyphenols Inhibit Phorbol Ester-Induced Superoxide Anion Formation in Cultured HL-60 Cells and Expression of Cyclooxygenase-2 and Activation of NF-KappaB and MAPKs in Mouse Skin in Vivo. J. Nutr. 2006, 136, 1150-1155. [CrossRef] [PubMed]

149. Scapagnini, G.; Davinelli, S.; Di Renzo, L.; De Lorenzo, A.; Olarte, H.H.; Micali, G.; Cicero, A.F.; Gonzalez, S. Cocoa Bioactive Compounds: Significance and Potential for the Maintenance of Skin Health. Nutrients 2014, 6, 3202-3213. [CrossRef]

150. Kim, J.-E.; Song, D.; Kim, J.; Choi, J.; Kim, J.R.; Yoon, H.-S.; Bae, J.-S.; Han, M.; Lee, S.; Hong, J.S.; et al. Oral Supplementation with Cocoa Extract Reduces UVB-Induced Wrinkles in Hairless Mouse Skin. J. Investig. Dermatol. 2016, 136, 1012-1021. [CrossRef]

151. Heinrich, U.; Neukam, K.; Tronnier, H.; Sies, H.; Stahl, W. Long-Term Ingestion of High Flavanol Cocoa Provides Photoprotection against UV-Induced Erythema and Improves Skin Condition in Women. J. Nutr. 2006, 136, 1565-1569. [CrossRef] [PubMed]

152. Calzavara-Pinton, P.; Calzavara-Pinton, I.; Arisi, M.; Rossi, M.T.; Scapagnini, G.; Davinelli, S.; Venturini, M. Cutaneous Photoprotective Activity of a Short-Term Ingestion of High-Flavanol Cocoa: A Nutritional Intervention Study. Photochem. Photobiol. 2019, 95, 1029-1034. [CrossRef]

153. Williams, S.; Tamburic, S.; Lally, C. Eating Chocolate Can Significantly Protect the Skin from UV Light. J. Cosmet. Dermatol. 2009, 8, 169-173. [CrossRef] [PubMed]

154. Mogollon, J.A.; Boivin, C.; Lemieux, S.; Blanchet, C.; Claveau, J.; Dodin, S. Chocolate Flavanols and Skin Photoprotection: A Parallel, Double-Blind, Randomized Clinical Trial. Nutr. J. 2014, 13, 1-12. [CrossRef] [PubMed]

155. Robbins, R.J. Phenolic Acids in Foods: An Overview of Analytical Methodology. J. Agric. Food Chem. 2003, 51, $2866-2887$. [CrossRef] [PubMed]

156. Bertram, J.S.; Vine, A.L. Cancer Prevention by Retinoids and Carotenoids: Independent Action on a Common Target. Carotenoids Diet. Lipids 2005, 1740, 170-178. [CrossRef]

157. Heinonen, M. Food Groups as the Source of Retinoids, Carotenoids, and Vitamin A in Finland. Int. J. Vitam. Nutr. Res. Int. Z. Vitam. Ernahr. J. Int. Vitaminol. Nutr. 1991, 61, 3-9. 
158. Ollilainen, V.; Heinonen, M.; Linkola, E.; Varo, P.; Koivistoinen, P. Carotenoids and Retinoids in Finnish Foods: Dairy Products and Eggs. J. Dairy Sci. 1989, 72, 2257-2265. [CrossRef]

159. Balić, A.; Mokos, M. Do We Utilize Our Knowledge of the Skin Protective Effects of Carotenoids Enough? Antioxidants 2019, 8, 259. [CrossRef]

160. Cheng, X.; Qian, W.; Chen, F.; Jin, Y.; Wang, F.; Lu, X.; Lee, S.R.; Su, D.; Chen, B. ATRA Protects Skin Fibroblasts against UV-induced Oxidative Damage through Inhibition of E3 Ligase Hrd1. Mol. Med. Rep. 2019, 20, 2294-2302. [CrossRef]

161. Darwiche, N.; Bazzi, H.; El-Touni, L.; Abou-Lteif, G.; Doueiri, R.; Hatoum, A.; Maalouf, S.; Gali-Muhtasib, H. Regulation of Ultraviolet B Radiation-Mediated Activation of AP1 Signaling by Retinoids in Primary Keratinocytes. Radiat. Res. 2005, 163, 296-306. [CrossRef]

162. Huang, C.; Ma, W.Y.; Dawson, M.I.; Rincon, M.; Flavell, R.A.; Dong, Z. Blocking Activator Protein-1 Activity, but Not Activating Retinoic Acid Response Element, Is Required for the Antitumor Promotion Effect of Retinoic Acid. Proc. Natl. Acad. Sci. USA 1997, 94, 5826-5830. [CrossRef]

163. Bécherel, P.-A.; Mossalayi, M.; Goff, L.; Francès, C.; Chosidow, O.; Debré, P.; Arock, M. Mechanism of Anti-Inflammatory Action of Retinoids on Keratinocytes. Lancet 1994, 344, 1570-1571. [CrossRef]

164. Bécherel, P.A.; Le Goff, L.; Ktorza, S.; Chosidow, O.; Francès, C.; Issaly, F.; Mencia-Huerta, J.M.; Debré, P.; Mossalayi, M.D.; Arock, M. CD23-Mediated Nitric Oxide Synthase Pathway Induction in Human Keratinocytes Is Inhibited by Retinoic Acid Derivatives. J. Investig. Dermatol. 1996, 106, 1182-1186. [CrossRef] [PubMed]

165. Kim, B.-H. Safety Evaluation and Anti-Wrinkle Effects of Retinoids on Skin. Toxicol. Res. 2010, 26, 61-66. [CrossRef] [PubMed]

166. Lerche, C.M.; Philipsen, P.A.; Sehested, M.; Wulf, H.C. Photocarcinogenesis of Topical Tazarotene and Isotretinoin Alone and in Combination with Valproic Acid in Hairless Mice. Exp. Dermatol. 2008, 17, 972-974. [CrossRef] [PubMed]

167. Sorg, O.; Iran, C.; Carraux, P.; Grand, D.; Hügin, A.; Didierjean, L.; Saurat, J.-H. Spectral Properties of Topical Retinoids Prevent DNA Damage and Apoptosis After Acute UV-B Exposure in Hairless Mice. Photochem. Photobiol. 2007, 81, 830-836. [CrossRef] [PubMed]

168. Epstein, J.H. Chemicals and Photocarcinogenesis*. Australas. J. Dermatol. 1977, 18, 57. [CrossRef]

169. Epstein, J.H.; Grekin, D.A. Inhibition of Ultraviolet-Induced Carcinogenesis by All-Trans Retinoic Acid. J. Investig. Dermatol. 1981, 76, 178-180. [CrossRef]

170. Mikkelsen, S.; Berne, B.; Staberg, B.; Vahlquist, A. Potentiating Effect of Dietary Vitamin A on Photocarcinogenesis in Hairless Mice. Carcinogenesis 1998, 19, 663-666. [CrossRef]

171. Halliday, G.M.; Robertson, B.O.; Barnetson, R.S.T.C. Topical Retinoic Acid Enhances, and a Dark Tan Protects, from Subedemal Solar-Simulated Photocarcinogenesis. J. Investig. Dermatol. 2000, 114, 923-927. [CrossRef]

172. Kligman, L.H.; Crosby, M.J. Topical Tretinoin Enhances Corticosteroid-Induced Inhibition of Tumorigenesis in Hairless Mice Previously Exposed to Solar Simulating Radiation. Cancer Lett. 1996, 107, 217-222. [CrossRef]

173. Kligman, L.H.; Kligman, A.M. Lack of Enhancement of Experimental Photocarcinogenesis by Topical Retinoic Acid. Arch. Dermatol. Res. 1981, 270, 453-462. [CrossRef]

174. Antille, C.; Tran, C.; Sorg, O.; Carraux, P.; Didierjean, L.; Saurat, J.-H. Vitamin A Exerts a Photoprotective Action in Skin by Absorbing Ultraviolet B Radiation. J. Investig. Dermatol. 2003, 121, 1163-1167. [CrossRef]

175. Smit, J.V.; de Jong, E.M.; de Jongh, G.J.; van de Kerkhof, P.C. Topical All-Trans Retinoic Acid Does Not Influence Minimal Erythema Doses for UVB Light in Normal Skin. Acta Derm. Venereol. 2000, 80, 66-67. [CrossRef] [PubMed]

176. Kim, J.; Park, M.K.; Li, W.-Q.; Qureshi, A.A.; Cho, E. Association of Vitamin A Intake with Cutaneous Squamous Cell Carcinoma Risk in the United States. JAMA Dermatol. 2019, 155, 1260-1268. [CrossRef] [PubMed]

177. Nijsten, T.E.C.; Stern, R.S. Oral Retinoid Use Reduces Cutaneous Squamous Cell Carcinoma Risk in Patients with Psoriasis Treated with Psoralen-UVA: A Nested Cohort Study. J. Am. Acad. Dermatol. 2003, 49, 644-650. [CrossRef]

178. Moon, T.E.; Levine, N.; Cartmel, B.; Bangert, J.L.; Rodney, S.; Dong, Q.; Peng, Y.M.; Alberts, D.S. Effect of Retinol in Preventing Squamous Cell Skin Cancer in Moderate-Risk Subjects: A Randomized, Double-Blind, Controlled Trial. Southwest Skin Cancer Prevention Study Group. Cancer Epidemiol. Biomark. Prev. Publ. Am. Assoc. Cancer Res. Cosponsored Am. Soc. Prev. Oncol. 1997, 6, 949-956.

179. Levine, N.; Moon, T.E.; Cartmel, B.; Bangert, J.L.; Rodney, S.; Dong, Q.; Peng, Y.M.; Alberts, D.S. Trial of Retinol and Isotretinoin in Skin Cancer Prevention: A Randomized, Double-Blind, Controlled Trial. Southwest Skin Cancer Prevention Study Group. Cancer Epidemiol. Biomark. Prev. Publ. Am. Assoc. Cancer Res. Cosponsored Am. Soc. Prev. Oncol. 1997, 6, 957-961.

180. PREISS, J.; HANDLER, P. Biosynthesis of Diphosphopyridine Nucleotide. II. Enzymatic Aspects. J. Biol. Chem. 1958, 233, 493-500. [CrossRef]

181. Bieganowski, P.; Brenner, C. Discoveries of Nicotinamide Riboside as a Nutrient and Conserved NRK Genes Establish a Preiss-Handler Independent Route to NAD+ in Fungi and Humans. Cell 2004, 117, 495-502. [CrossRef]

182. Belenky, P.; Bogan, K.L.; Brenner, C. NAD+ Metabolism in Health and Disease. Trends Biochem. Sci. 2007, 32, 12-19. [CrossRef] [PubMed]

183. Surjana, D.; Halliday, G.M.; Damian, D.L. Role of Nicotinamide in DNA Damage, Mutagenesis, and DNA Repair. J. Nucleic Acids 2010, 2010, 157591. [CrossRef] 
184. Robu, M.; Shah, R.G.; Petitclerc, N.; Brind'Amour, J.; Kandan-Kulangara, F.; Shah, G.M. Role of Poly(ADP-Ribose) Polymerase-1 in the Removal of UV-Induced DNA Lesions by Nucleotide Excision Repair. Proc. Natl. Acad. Sci. USA 2013, 110, $1658-1663$. [CrossRef] [PubMed]

185. Cao, C.; Lu, S.; Kivlin, R.; Wallin, B.; Card, E.; Bagdasarian, A.; Tamakloe, T.; Wang, W.; Song, X.; Chu, W.; et al. SIRT1 Confers Protection against UVB- and H2O2-Induced Cell Death via Modulation of P53 and JNK in Cultured Skin Keratinocytes. J. Cell. Mol. Med. 2009, 13, 3632-3643. [CrossRef] [PubMed]

186. Surjana, D.; Halliday, G.M.; Damian, D.L. Nicotinamide Enhances Repair of Ultraviolet Radiation-Induced DNA Damage in Human Keratinocytes and Ex Vivo Skin. Carcinogenesis 2013, 34, 1144-1149. [CrossRef]

187. Monfrecola, G.; Gaudiello, F.; Cirillo, T.; Fabbrocini, G.; Balato, A.; Lembo, S. Nicotinamide Downregulates Gene Expression of Interleukin-6, Interleukin-10, Monocyte Chemoattractant Protein-1, and Tumour Necrosis Factor- $\alpha$ Gene Expression in HaCaT Keratinocytes after Ultraviolet B Irradiation. Clin. Exp. Dermatol. 2013, 38, 185-188. [CrossRef]

188. Monfrecola, G.; Di Caprio, R.; Balato, N.; Bevilacqua, M.A.; Iovine, B.; Lembo, S.; Balato, A. Nicotinamide Reduces Cyclooxygenase-2 Expression in HaCaT Keratinocytes after Ultraviolet-B Irradiation. Br. J. Dermatol. 2017, 176, 1402-1404. [CrossRef]

189. Gensler, H.L. Prevention of Photoimmunosuppression and Photocarcinogenesis by Topical Nicotinamide. Nutr. Cancer 1997, 29, 157-162. [CrossRef]

190. Gensler, H.L.; Williams, T.; Huang, A.C.; Jacobson, E.L. Oral Niacin Prevents Photocarcinogenesis and Photoimmunosuppression in Mice. Nutr. Cancer 1999, 34, 36-41. [CrossRef] [PubMed]

191. Damian, D.L.; Patterson, C.R.S.; Stapelberg, M.; Park, J.; Barnetson, R.S.C.; Halliday, G.M. UV Radiation-Induced Immunosuppression Is Greater in Men and Prevented by Topical Nicotinamide. J. Investig. Dermatol. 2008, 128, 447-454. [CrossRef]

192. Sivapirabu, G.; Yiasemides, E.; Halliday, G.M.; Park, J.; Damian, D.L. Topical Nicotinamide Modulates Cellular Energy Metabolism and Provides Broad-Spectrum Protection against Ultraviolet Radiation-Induced Immunosuppression in Humans. Br. J. Dermatol. 2009, 161, 1357-1364. [CrossRef]

193. Yiasemides, E.; Sivapirabu, G.; Halliday, G.M.; Park, J.; Damian, D.L. Oral Nicotinamide Protects against Ultraviolet RadiationInduced Immunosuppression in Humans. Carcinogenesis 2009, 30, 101-105. [CrossRef]

194. Surjana, D.; Halliday, G.M.; Martin, A.J.; Moloney, F.J.; Damian, D.L. Oral Nicotinamide Reduces Actinic Keratoses in Phase II Double-Blinded Randomized Controlled Trials. J. Investig. Dermatol. 2012, 132, 1497-1500. [CrossRef] [PubMed]

195. Chen, A.C.; Martin, A.J.; Choy, B.; Fernández-Peñas, P.; Dalziell, R.A.; McKenzie, C.A.; Scolyer, R.A.; Dhillon, H.M.; Vardy, J.L.; Kricker, A.; et al. A Phase 3 Randomized Trial of Nicotinamide for Skin-Cancer Chemoprevention. N. Engl. J. Med. 2015, 373, 1618-1626. [CrossRef] [PubMed]

196. Zhao, Y. Nicotinamide for Skin-Cancer Chemoprevention. N. Engl. J. Med. 2016, 374, 789-790. [CrossRef] [PubMed]

197. Kyme, P.; Thoennissen, N.H.; Tseng, C.W.; Thoennissen, G.B.; Wolf, A.J.; Shimada, K.; Krug, U.O.; Lee, K.; Müller-Tidow, C.; Berdel, W.E.; et al. C/EBPE Mediates Nicotinamide-Enhanced Clearance of Staphylococcus Aureus in Mice. J. Clin. Investig. 2012, 122, 3316-3329. [CrossRef]

198. Ciebiada-Adamiec, A.; Małafiej, E.; Ciebiada, I. Inhibitory Effect of Nicotinamide on Enzymatic Activity of Selected Fungal Strains Causing Skin Infection. Mycoses 2010, 53, 204-207. [CrossRef] [PubMed]

199. Yélamos, O.; Halpern, A.C.; Weinstock, M.A. Reply to 'A Phase II Randomized Controlled Trial of Nicotinamide for Skin Cancer Chemoprevention in Renal Transplant Recipients'. Br. J. Dermatol. 2017, 176, 551-552. [CrossRef]

200. Boyce, S.T.; Supp, A.P.; Swope, V.B.; Warden, G.D. Vitamin C Regulates Keratinocyte Viability, Epidermal Barrier, and Basement Membrane In Vitro, and Reduces Wound Contraction After Grafting of Cultured Skin Substitutes. J. Investig. Dermatol. 2002, 118, 565-572. [CrossRef]

201. Smirnoff, N.; Conklin, P.L.; Loewus, F.A. Biosynthesis of Ascorbic Acid in Plants: A Renaissance. Annu. Rev. Plant Physiol. Plant Mol. Biol. 2001, 52, 437-467. [CrossRef]

202. Kang, J.S.; Kim, H.N.; Jung, D.J.; Kim, J.E.; Mun, G.H.; Kim, Y.S.; Cho, D.; Shin, D.H.; Hwang, Y.-I.; Lee, W.J. Regulation of UVB-Induced IL-8 and MCP-1 Production in Skin Keratinocytes by Increasing Vitamin C Uptake via the Redistribution of SVCT-1 from the Cytosol to the Membrane. J. Investig. Dermatol. 2007, 127, 698-706. [CrossRef] [PubMed]

203. Stewart, M.S.; Cameron, G.S.; Pence, B.C. Antioxidant Nutrients Protect against UVB-Induced Oxidative Damage to DNA of Mouse Keratinocytes in Culture. J. Investig. Dermatol. 1996, 106, 1086-1089. [CrossRef] [PubMed]

204. Tebbe, B.; Wu, S.; Geilen, C.C.; Eberle, J.; Kodelja, V.; Orfanos, C.E. L-Ascorbic Acid Inhibits UVA-Induced Lipid Peroxidation and Secretion of IL-1alpha and IL-6 in Cultured Human Keratinocytes in Vitro. J. Investig. Dermatol. 1997, 108, 302-306. [CrossRef] [PubMed]

205. Kawashima, S.; Funakoshi, T.; Sato, Y.; Saito, N.; Ohsawa, H.; Kurita, K.; Nagata, K.; Yoshida, M.; Ishigami, A. Protective Effect of Pre- and Post-Vitamin C Treatments on UVB-Irradiation-Induced Skin Damage. Sci. Rep. 2018, 8, 16199. [CrossRef] [PubMed]

206. Lin, J.; Qin, H.; Wu, W.; He, S.; Xu, J. Vitamin C Protects against UV Irradiation-Induced Apoptosis through Reactivating Silenced Tumor Suppressor Genes P21 and P16 in a Tet-Dependent DNA Demethylation Manner in Human Skin Cancer Cells. Cancer Biother. Radiopharm. 2014, 29, 257-264. [CrossRef] [PubMed]

207. Dunham, W.B.; Zuckerkandl, E.; Reynolds, R.; Willoughby, R.; Marcuson, R.; Barth, R.; Pauling, L. Effects of Intake of L-Ascorbic Acid on the Incidence of Dermal Neoplasms Induced in Mice by Ultraviolet Light. Proc. Natl. Acad. Sci. USA 1982, 79, 7532-7536. [CrossRef] [PubMed] 
208. Pauling, L. Effect of Ascorbic Acid on Incidence of Spontaneous Mammary Tumors and UV-Light-Induced Skin Tumors in Mice. Am. J. Clin. Nutr. 1991, 54, 1252S-1255S. [CrossRef]

209. McArdle, F.; Rhodes, L.E.; Parslew, R.; Jack, C.I.A.; Friedmann, P.S.; Jackson, M.J. UVR-Induced Oxidative Stress in Human Skin in Vivo: Effects of Oral Vitamin C Supplementation. Free Radic. Biol. Med. 2002, 33, 1355-1362. [CrossRef]

210. Mireles-Rocha, H.; Galindo, I.; Huerta, M.; Trujillo-Hernández, B.; Elizalde, A.; Cortés-Franco, R. UVB Photoprotection with Antioxidants: Effects of Oral Therapy with d-Alpha-Tocopherol and Ascorbic Acid on the Minimal Erythema Dose. Acta Derm. Venereol. 2002, 82, 21-24. [CrossRef]

211. Fuchs, J.; Kern, H. Modulation of UV-Light-Induced Skin Inflammation by D-Alpha-Tocopherol and L-Ascorbic Acid: A Clinical Study Using Solar Simulated Radiation. Free Radic. Biol. Med. 1998, 25, 1006-1012. [CrossRef]

212. Dreher, F.; Gabard, B.; Schwindt, D.A.; Maibach, H.I. Topical Melatonin in Combination with Vitamins E and C Protects Skin from Ultraviolet-Induced Erythema: A Human Study in Vivo. Br. J. Dermatol. 1998, 139, 332-339. [CrossRef] [PubMed]

213. Dreher, F.; Denig, N.; Gabard, B.; Schwindt, D.A.; Maibach, H.I. Effect of Topical Antioxidants on UV-Induced Erythema Formation When Administered after Exposure. Dermatology 1999, 198, 52-55. [CrossRef] [PubMed]

214. Fung, T.T.; Spiegelman, D.; Egan, K.M.; Giovannucci, E.; Hunter, D.J.; Willett, W.C. Vitamin and Carotenoid Intake and Risk of Squamous Cell Carcinoma of the Skin. Int. J. Cancer 2003, 103, 110-115. [CrossRef]

215. Fung, T.T.; Hunter, D.J.; Spiegelman, D.; Colditz, G.A.; Speizer, F.E.; Willett, W.C. Vitamins and Carotenoids Intake and the Risk of Basal Cell Carcinoma of the Skin in Women (United States). Cancer Causes Control CCC 2002, 13, 221-230. [CrossRef] [PubMed]

216. Placzek, M.; Gaube, S.; Kerkmann, U.; Gilbertz, K.-P.; Herzinger, T.; Haen, E.; Przybilla, B. Ultraviolet B-Induced DNA Damage in Human Epidermis Is Modified by the Antioxidants Ascorbic Acid and D- $\alpha$-Tocopherol. J. Investig. Dermatol. 2005, 124, 304-307. [CrossRef]

217. Eberlein-König, B.; Placzek, M.; Przybilla, B. Protective Effect against Sunburn of Combined Systemic Ascorbic Acid (Vitamin C) and d- $\alpha$-Tocopherol (Vitamin E). J. Am. Acad. Dermatol. 1998, 38, 45-48. [CrossRef]

218. Oresajo, C.; Stephens, T.; Hino, P.D.; Law, R.M.; Yatskayer, M.; Foltis, P.; Pillai, S.; Pinnell, S.R. Protective Effects of a Topical Antioxidant Mixture Containing Vitamin C, Ferulic Acid, and Phloretin against Ultraviolet-Induced Photodamage in Human Skin. J. Cosmet. Dermatol. 2008, 7, 290-297. [CrossRef]

219. Bikle, D.D. Vitamin D Metabolism and Function in the Skin. Mol. Cell. Endocrinol. 2011, 347, 80-89. [CrossRef]

220. Reichrath, J.; Reichrath, S.; Heyne, K.; Vogt, T.; Roemer, K. Tumor Suppression in Skin and Other Tissues via Cross-Talk between Vitamin D- and P53-Signaling. Front. Physiol. 2014, 5, 166. [CrossRef]

221. Gupta, R.; Dixon, K.M.; Deo, S.S.; Holliday, C.J.; Slater, M.; Halliday, G.M.; Reeve, V.E.; Mason, R.S. Photoprotection by 1,25 Dihydroxyvitamin D3 Is Associated with an Increase in P53 and a Decrease in Nitric Oxide Products. J. Investig. Dermatol. 2007, 127, 707-715. [CrossRef]

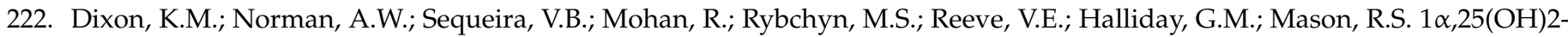
Vitamin D and a Nongenomic Vitamin D Analogue Inhibit Ultraviolet Radiation-Induced Skin Carcinogenesis. Cancer Prev. Res. 2011, 4, 1485. [CrossRef]

223. Wong, G.; Gupta, R.; Dixon, K.M.; Deo, S.S.; Choong, S.M.; Halliday, G.M.; Bishop, J.E.; Ishizuka, S.; Norman, A.W.; Posner, G.H.; et al. 1,25-Dihydroxyvitamin D and Three Low-Calcemic Analogs Decrease UV-Induced DNA Damage via the Rapid Response Pathway. J. Steroid Biochem. Mol. Biol. 2004, 89-90, 567-570. [CrossRef] [PubMed]

224. De Haes, P.; Garmyn, M.; Verstuyf, A.; De Clercq, P.; Vandewalle, M.; Degreef, H.; Vantieghem, K.; Bouillon, R.; Segaert, S. 1,25-Dihydroxyvitamin D3 and Analogues Protect Primary Human Keratinocytes against UVB-Induced DNA Damage. J. Photochem. Photobiol. B 2005, 78, 141-148. [CrossRef] [PubMed]

225. Song, E.J.; Gordon-Thomson, C.; Cole, L.; Stern, H.; Halliday, G.M.; Damian, D.L.; Reeve, V.E.; Mason, R.S. 1 1 2 ,25Dihydroxyvitamin D-3 Reduces Several Types of UV-Induced DNA Damage and Contributes to Photoprotection. J. STEROID Biochem. Mol. Biol. 2013, 136, 131-138. [CrossRef] [PubMed]

226. Dixon, K.M.; Sequeira, V.B.; Deo, S.S.; Mohan, R.; Posner, G.H.; Mason, R.S. Differential Photoprotective Effects of 1,25Dihydroxyvitamin D3 and a Low Calcaemic Deltanoid. Photochem. Photobiol. Sci. Off. J. Eur. Photochem. Assoc. Eur. Soc. Photobiol. 2012, 11, 1825-1830. [CrossRef]

227. Kim, J.S.; Jung, M.; Yoo, J.; Choi, E.H.; Park, B.C.; Kim, M.H.; Hong, S.P. Protective Effect of Topical Vitamin D3 against Photocarcinogenesis in a Murine Model. Ann Derm. 2016, 28, 304-313. [CrossRef]

228. Scott, J.F.; Das, L.M.; Ahsanuddin, S.; Qiu, Y.; Binko, A.M.; Traylor, Z.P.; Debanne, S.M.; Cooper, K.D.; Boxer, R.; Lu, K.Q. Oral Vitamin D Rapidly Attenuates Inflammation from Sunburn: An Interventional Study. J. Investig. Dermatol. 2017, 137, 2078-2086. [CrossRef]

229. Ellison, T.I.; Smith, M.K.; Gilliam, A.C.; MacDonald, P.N. Inactivation of the Vitamin D Receptor Enhances Susceptibility of Murine Skin to UV-Induced Tumorigenesis. J. Investig. Dermatol. 2008, 128, 2508-2517. [CrossRef]

230. Sequeira, V.B.; Rybchyn, M.S.; Tongkao-On, W.; Gordon-Thomson, C.; Malloy, P.J.; Nemere, I.; Norman, A.W.; Reeve, V.E.; Halliday, G.M.; Feldman, D.; et al. The Role of the Vitamin D Receptor and ERp57 in Photoprotection by 1 $\alpha, 25$-Dihydroxyvitamin D3. Mol. Endocrinol. 2012, 26, 574-582. [CrossRef]

231. Munne-Bosch, S.; Alegre, L. The Function of Tocopherols and Tocotrienols in Plants. Crit. Rev. Plant Sci. 2002, 21, 31-57. [CrossRef] 
232. Jurkiewicz, B.A.; Bissett, D.L.; Buettner, G.R. Effect of Topically Applied Tocopherol on Ultraviolet Radiation-Mediated Free Radical Damage in Skin. J. Investig. Dermatol. 1995, 104, 484-488. [CrossRef] [PubMed]

233. Delinasios, G.J.; Karbaschi, M.; Cooke, M.S.; Young, A.R. Vitamin E Inhibits the UVAI Induction of "Light" and "Dark" Cyclobutane Pyrimidine Dimers, and Oxidatively Generated DNA Damage, in Keratinocytes. Sci. Rep. 2018, 8, 423. [CrossRef] [PubMed]

234. Wu, C.; Cheng, Y.; Dai, Y.; Chen, M.; Wang, C. A-Tocopherol Protects Keratinocytes against Ultraviolet A Irradiation by Suppressing Glutathione Depletion, Lipid Peroxidation and Reactive Oxygen Species Generation. Biomed. Rep. 2014, 2, 419-423. [CrossRef]

235. Maalouf, S.; El-Sabban, M.; Darwiche, N.; Gali-Muhtasib, H. Protective Effect of Vitamin E on Ultraviolet B Light-Induced Damage in Keratinocytes. Mol. Carcinog. 2002, 34, 121-130. [CrossRef]

236. Jin, G.-H.; Liu, Y.; Jin, S.-Z.; Liu, X.-D.; Liu, S.-Z. UVB Induced Oxidative Stress in Human Keratinocytes and Protective Effect of Antioxidant Agents. Radiat. Environ. Biophys. 2007, 46, 61-68. [CrossRef]

237. Trevithick, J.R.; Xiong, H.; Lee, S.; Shum, D.T.; Sanford, S.E.; Karlik, S.J.; Norley, C.; Dilworth, G.R. Topical Tocopherol Acetate Reduces Post-UVB, Sunburn-Associated Erythema, Edema, and Skin Sensitivity in Hairless Mice. Arch. Biochem. Biophys. 1992, 296, 575-582. [CrossRef]

238. Roshchupkin, D.I.; Pistsov, M.Y.; Potapenko, A.Y. Inhibition of Ultraviolet Light-Induced Erythema by Antioxidants. Arch. Dermatol. Res. 1979, 266, 91-94. [CrossRef] [PubMed]

239. Gensler, H.L.; Magdaleno, M. Topical Vitamin E Inhibition of Immunosuppression and Tumorigenesis Induced by Ultraviolet Irradiation. Nutr. Cancer 1991, 15, 97-106. [CrossRef] [PubMed]

240. Kuchide, M.; Tokuda, H.; Takayasu, J.; Enjo, F.; Ishikawa, T.; Ichiishi, E.; Naito, Y.; Yoshida, N.; Yoshikawa, T.; Nishino, H. Cancer Chemopreventive Effects of Oral Feeding Alpha-Tocopherol on Ultraviolet Light B Induced Photocarcinogenesis of Hairless Mouse. Cancer Lett. 2003, 196, 169-177. [CrossRef]

241. Burns, E.M.; Tober, K.L.; Riggenbach, J.A.; Kusewitt, D.F.; Young, G.S.; Oberyszyn, T.M. Differential Effects of Topical Vitamin E and C E Ferulic ${ }^{\circledR}$ Treatments on Ultraviolet Light B-Induced Cutaneous Tumor Development in Skh-1 Mice. PLoS ONE 2013, 8, e63809. [CrossRef]

242. Werninghaus, K.; Meydani, M.; Bhawan, J.; Margolis, R.; Blumberg, J.B.; Gilchrest, B.A. Evaluation of the Photoprotective Effect of Oral Vitamin E Supplementation. Arch. Dermatol. 1994, 130, 1257-1261. [CrossRef] [PubMed]

243. McArdle, F.; Rhodes, L.E.; Parslew, R.A.G.; Close, G.L.; Jack, C.I.A.; Friedmann, P.S.; Jackson, M.J. Effects of Oral Vitamin E and Beta-Carotene Supplementation on Ultraviolet Radiation-Induced Oxidative Stress in Human Skin. Am. J. Clin. Nutr. 2004, 80, 1270-1275. [CrossRef] [PubMed]

244. Lin, J.-Y.; Selim, M.A.; Shea, C.R.; Grichnik, J.M.; Omar, M.M.; Monteiro-Riviere, N.A.; Pinnell, S.R. UV Photoprotection by Combination Topical Antioxidants Vitamin C and Vitamin E. J. Am. Acad. Dermatol. 2003, 48, 866-874. [CrossRef]

245. Lin, F.-H.; Lin, J.-Y.; Gupta, R.D.; Tournas, J.A.; Burch, J.A.; Angelica Selim, M.; Monteiro-Riviere, N.A.; Grichnik, J.M.; Zielinski, J.; Pinnell, S.R. Ferulic Acid Stabilizes a Solution of Vitamins C and E and Doubles Its Photoprotection of Skin. J. Investig. Dermatol. 2005, 125, 826-832. [CrossRef]

246. Sugiyama, T.; Sadzuka, Y. Enhancing Effects of Green Tea Components on the Antitumor Activity of Adriamycin against M5076 Ovarian Sarcoma. Cancer Lett. 1998, 133, 19-26. [CrossRef]

247. Mehendale, S.; Aung, H.; Wang, A.; Yin, J.-J.; Wang, C.-Z.; Xie, J.-T.; Yuan, C.-S. American Ginseng Berry Extract and Ginsenoside Re Attenuate Cisplatin-Induced Kaolin Intake in Rats. Cancer Chemother. Pharmacol. 2005, 56, 63-69. [CrossRef]

248. Sak, K. Chemotherapy and Dietary Phytochemical Agents. Chemother. Res. Pract. 2012, 2012, 282570. [CrossRef] 